
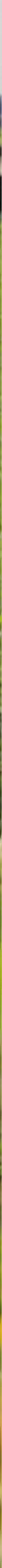

Mineralenprestaties van de melkveehouderij in Noord-Nederland

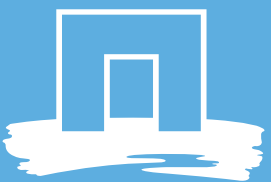





\section{Mineralenprestaties van de melkveehouderij in Noord-Nederland}

M. Timmerman, M. Plomp, M.H.A. de Haan

Wageningen Livestock Research

Dit onderzoek is uitgevoerd door Wageningen Livestock Research, in opdracht van en gefinancierd door de Versnellingsagenda melkveehouderij Noord-Nederland.

Wageningen Livestock Research

Wageningen, juni 2019 
Timmerman, M., M. Plomp, M.H.A. de Haan, 2019. Mineralenprestaties van de melkveehouderij in Noord-Nederland. Wageningen Livestock Research, Rapport 1173.

\section{Samenvatting}

In deze studie zijn gerealiseerde bodemoverschotten ( $N$ en P2O5), ammoniak- en broeikasgasemissies en het percentage eiwit van eigen land van de melkveehouderij in Noord-Nederland voor de jaren 2016 en 2017 vastgesteld. De gerealiseerde waarden zijn vervolgens vergeleken met eerder gepubliceerde resultaten over 2013.

\section{Summary}

In this study the realized soil surpluses ( $\mathrm{N}$ and P2O5), ammonia- and greenhouse gas emissions and the percentage protein of own land of the dairy farms in the Northern part of the Netherlands have been established for the years 2016 and 2017. The realized values were subsequently compared with previous published results over 2013.

Dit rapport is gratis te downloaden op https://doi.org/10.18174/479027 of op www.wur.nl/livestock-research (onder Wageningen Livestock Research publicaties).

\section{(C) 2019 Wageningen Livestock Research}

Postbus 338, 6700 AH Wageningen, T 03174839 53, E info.livestockresearch@wur.nl, www.wur.nl/livestock-research. Wageningen Livestock Research is onderdeel van Wageningen University \& Research.

Wageningen Livestock Research aanvaardt geen aansprakelijkheid voor eventuele schade voortvloeiend uit het gebruik van de resultaten van dit onderzoek of de toepassing van de adviezen.

Alle rechten voorbehouden. Niets uit deze uitgave mag worden vermenigvuldigd en/of openbaar gemaakt worden door middel van druk, fotokopie, microfilm of op welke wijze dan ook zonder voorafgaande toestemming van de uitgever of auteur.

Wageningen Livestock Research is NEN-EN-ISO 9001:2015 gecertificeerd. Op al onze onderzoeksopdrachten zijn de Algemene Voorwaarden van de Animal Sciences Group van toepassing. Deze zijn gedeponeerd bij de Arrondissementsrechtbank Zwolle. 


\section{Inhoud}

$\begin{array}{ll}\text { Samenvatting } & 5\end{array}$

1

$\begin{array}{ll}\text { Inleiding } & 7\end{array}$

$\begin{array}{lll}1.1 & \text { Aanleiding } & 7\end{array}$

$\begin{array}{lll}1.2 & \text { Doel } & 7\end{array}$

$\begin{array}{llr}2 & \text { Materiaal en Methode } & 8\end{array}$

2.1 Gegevens referentiejaar $2013 \quad 8$

2.2 Gegevens jaren 2017 en 2018

$\begin{array}{llr}3 & \text { Resultaten } & 10\end{array}$

$\begin{array}{lll}3.1 & \text { Bedrijfsstructuur melkveehouderij } & 10\end{array}$

3.2 Stikstof- en fosfaatbodemoverschot $\quad 13$

$\begin{array}{lll}3.3 & \text { Broeikasgasemissie } & 14\end{array}$

$\begin{array}{lll}3.4 & \text { Ammoniakemissie } & 15\end{array}$

$\begin{array}{lll}3.5 & \text { Eiwit van eigen land } & 15\end{array}$

3.6 Resultaten van de $25 \%$ best scorende bedrijven in Noord-Nederland 16

$\begin{array}{ll}\text { Discussie } & 20\end{array}$

$5 \quad$ Conclusies en aanbevelingen $\quad 22$

$\begin{array}{lll}5.1 & \text { Conclusies } & 22\end{array}$

$\begin{array}{lll}5.2 & \text { Aanbevelingen } & 22\end{array}$

$\begin{array}{ll}\text { Literatuur } & 23\end{array}$

Bijlage 1 Doelen versnellingsagenda melkveehouderij Noord-Nederland 24

Bijlage 2 Overzicht mineralenprestaties 2016

$\begin{array}{lll}\text { Bijlage } 3 \text { Overzicht mineralenprestaties } 2017 & 27\end{array}$

Bijlage 4 Resultaten Nederland en Noord-Nederland 2013, 2016 en 201729

Bijlage 5 Resultaten per provincie over 2016 en 201730

Bijlage 6 Resultaten per grondsoort over 2016 en 2017 



\section{Samenvatting}

In 2015 is in opdracht van de Versnellingsagenda melkveehouderij Noord-Nederland geïnventariseerd hoe de melkveehouderij in Noord-Nederland in 2013 scoorde op de kengetallen stikstof- en fosfaatbodemoverschot, broeikasgasemissies en ammoniakemissie (Daatselaar et al., 2015). De Versnellingsagenda wil weten wat de gerealiseerde resultaten zijn voor 2016 en 2017 voor deze kengetallen, aangevuld met het kengetal 'percentage eiwit van eigen land'. De resultaten voor de jaren 2016 en 2017 zijn vastgesteld op basis van de resultaten van de KringloopWijzer en vergeleken met de resultaten uit 2013. Daarnaast zijn de gemiddelde resultaten van Noord-Nederland vergeleken met de gemiddelde resultaten van heel Nederland.

Aangezien de rekenmethodiek voor de broeikasgasemissie in de KringloopWijzer versie 2016 is aangepast t.o.v. voorgaande jaren, zijn de resultaten uit 2013 voor de broeikasgasemissie gecorrigeerd voor het effect van de gewijzigde rekenmethodiek. De totale broeikasgasemissie over 2013 was niet bekend, alleen het on-farm gedeelte.

In tabel A staan de gemiddelde mineralenprestaties van de melkveebedrijven in Noord-Nederland (Drenthe, Friesland en Groningen).

Tabel A Gemiddelde mineralenprestaties van de melkveebedrijven in Noord-Nederland.

\begin{tabular}{|c|c|c|c|}
\hline Kengetal & 2013 & 2016 & 2017 \\
\hline N-bodemoverschot excl. veenmineralisatie $(\mathrm{kg} / \mathrm{ha})$ & 126 & 101 & 105 \\
\hline Broeikasgasemissie on-farm (kg CO2-eq./ha) & 14.873 & 15.765 & 15.865 \\
\hline Broeikasgasemissie totaal (kg CO2-eq./ha) & - & 21.433 & 22.123 \\
\hline Broeikasgasemissie on-farm (kg CO2-eq./ton melk) & 1.166 & 1.106 & 1.098 \\
\hline NH3-emissie (kg/ha) & 59,0 & 66,1 & 65,3 \\
\hline NH3-emissie (kg/GVE) & 27,0 & 30,0 & 30,9 \\
\hline Aandeel eiwit van eigen land (\%) & - & 68 & 69 \\
\hline
\end{tabular}

De gemiddelde resultaten van de melkveebedrijven in Noord-Nederland laten t.o.v. de uitgangssituatie in 2013 de volgende ontwikkelingen zien:

- Het gemiddelde stikstofbodemoverschot in 2016 en 2017 ligt ca 29 kg lager dan de uitgangssituatie in 2013 . Dit is een afname van $17 \%$. Ook het $\mathrm{N}$-bodemoverschot exclusief veenmineralisatie is met circa $17 \%$ afgenomen.

- Het fosfaatbodemoverschot is gedaald van een positief overschot in $2013(+12 \mathrm{~kg} / \mathrm{ha})$ naar een negatief overschot in 2016 (-7 kg/ha) en 2017 ( $-4 \mathrm{~kg} / \mathrm{ha})$.

- De on-farm broeikasgasemissie per hectare is t.o.v. 2013 gestegen met 7\%.

- De on-farm broeikasgasemissie per ton melk is t.o.v. 2013 gedaald met $6 \%$.

- De ammoniakemissie per hectare is gestegen, van $59 \mathrm{~kg} / \mathrm{ha}$ naar circa $66 \mathrm{~kg} / \mathrm{ha}$ in 2016/2017, een toename van $11 \%$.

- Ook de ammoniakemissie per GVE is gestegen, van 27,0 kg/GVE naar circa 30,4 kg/GVE in $2016 / 2017$, een toename van $13 \%$.

- Het aandeel eiwit van eigen land ligt met 68\% (2016) en 69\% (2017) ruim boven de 65\%.

Samenvattend kunnen we stellen dat de mineralenprestaties van de melkveehouderij in NoordNederland op de kengetallen stikstof- en fosfaatbodemoverschot zijn verbeterd t.o.v. 2013. Waarschijnlijk wordt dit deels veroorzaakt door efficiënter werken en deels ook het ingezette beleid van sector en overheid (lagere fosfaatnormen, minder fosfor in (meng)voer). Daarentegen is de ammoniakemissie per ha en per GVE gestegen. De broeikasgasemissies zijn enerzijds per hectare toegenomen, maar anderzijds per ton melk afgenomen. Mogelijke verklaringen hiervoor zijn onder andere de gestegen melkproductie per ha en per koe. De streefwaarde van $65 \%$ eiwit van eigen land wordt zowel in 2016 als in 2017 ruimschoots gehaald. 


\section{$1 \quad$ Inleiding}

\section{$1.1 \quad$ Aanleiding}

In opdracht van de Versnellingsagenda Melkveehouderij Noord-Nederland heeft Wageningen Economic Research (WECR) in 2015 gegevens over de kengetallen stikstof- en fosfaatbodemoverschot, broeikasgasemissie en ammoniakemissie geïnventariseerd voor de melkveehouderij in NoordNederland over het jaar 2013. Tevens heeft WEcR een advies gegeven voor streefwaarden op basis van het gemiddelde van de $25 \%$ best scorende bedrijven op elk kengetal. Op grond van o.a. de studie van WEcR heeft de Versnellingsagenda melkveehouderij Noord-Nederland voor deze kengetallen doelen voor 2020 geformuleerd, zie bijlage 1. De Versnellingsagenda wil graag inzicht in de ontwikkeling van de resultaten voor deze kengetallen en ook inzicht in het resultaat van het kengetal 'percentage eiwit van eigen land'.

\subsection{Doel}

Het vaststellen van de gerealiseerde bodemoverschotten ( $N$ en P2O5), ammoniak- en broeikasgasemissies en het percentage eiwit van eigen land van de melkveehouderij in NoordNederland voor de jaren 2016 en 2017 op basis van de resultaten van de KringloopWijzer en deze vergelijken met eerder berekende resultaten uit 2013. 


\section{Materiaal en Methode}

\section{$2.1 \quad$ Gegevens referentiejaar 2013}

Voor de Versnellingsagenda melkveehouderij Noord-Nederland heeft Wageningen Economic Research (WECR) in 2015 voor de melkveehouderij in Noord-Nederland de streefwaarden berekend van de volgende indicatoren:

- Stikstofbodemoverschot (in $\mathrm{kg} / \mathrm{ha}$ )

- Fosfaatbodemoverschot (in kg/ha)

- Broeikasgasemissie (in kg CO2-equivalent per kg melk)

- Ammoniakemissie (in kg/ha en kg/GVE).

De streefwaarden zijn gekwantificeerd als het niveau waaraan de beste $25 \%$ van de bedrijven minimaal voldoet (Daatselaar et al., 2015).

De volgende berekeningsmethodiek is in de studie uit 2015 gehanteerd om de streefwaarden te berekenen (Daatselaar, 2018):

- Er zijn ruim 4.000 melkveebedrijven uit de CBS Landbouwtelling 2013 genomen (zijnde de gangbare melkveebedrijven in Groningen, Friesland en Drenthe in 2013). Daar is een 90-tal best passende bedrijven uit het WECR-BedrijvenInformatieNet (BIN) 2013 gekoppeld, aangezien dat destijds de meeste recente beschikbare cijfers waren.

- Vervolgens is van het best passende BIN-bedrijf de KringloopWijzer berekend met de KringloopWijzer versie uit 2015 en toegekend aan het betreffende melkveebedrijf in de Landbouwtelling.

- Met uitkomsten van de KringloopWijzer 2015 zijn de berekeningen van streefwaarden uitgevoerd.

De volgende uitgangspunten zijn in de studie uit 2015 gehanteerd (Daatselaar et al., 2015; Daatselaar, 2018):

- Er is alleen gebruik gemaakt van de resultaten van gangbare bedrijven, en niet van biologisch (dynamische) bedrijven.

- De belangrijkste grondsoort in het postcodegebied van het bedrijfsgebouw is toegewezen als zijnde de grondsoort van het bedrijf. Dit betekent dat een bedrijf of zand of veen of een klei-bedrijf was, naar gelang wat het hoogste aandeel had in het postcodegebied. Er is geen overige categorie gebruikt waarin bedrijven zaten met meerdere grondsoorten.

- De resultaten zijn niet omgerekend naar kg meetmelk.

- De berekende broeikasgasemissie betrof alleen de directe emissie op het bedrijf (de on-farm broeikasgasemissie) en niet de off-farm emissies.

De rekenmethodiek van de KringloopWijzer wordt jaarlijks geactualiseerd, waaronder ook de berekening van de broeikasgasemissies. Zo is ook de versie van 2015 aangepast (o.a. aanpassing methaanemissie pens en $\mathrm{CO} 2$ voor aanvoer van voedermiddelen) naar de vernieuwde versies van 2016 en 2017. Om een beeld te krijgen van de grootte van het rekenkundig effect voor broeikasgasemissies en de verschillen t.o.v. de situatie in 2013 zijn de resultaten van de Koeien \& Kansen bedrijven van 2015 doorgerekend met twee verschillende versies van de KLW (2017 en 2015). Dit resulteerde in een hogere on-farm emissie per kg melk van gemiddeld $6 \%$ in de KLW-versie van 2017 t.o.v. de KLW-versie van 2015. Per hectare was de on-farm broeikasgasemissie gemiddeld $7 \%$ hoger. Voor een betere vergelijking tussen de resultaten over 2013 en 2016-2017 zijn de gerapporteerde on-farm broeikasgasemissies over 2013 verhoogd met deze berekende percentages.

\subsection{Gegevens jaren 2017 en 2018}

ZuivelNL heeft de geanonimiseerde datasets over 2016 en 2017 uit de Centrale Database KringloopWijzer (CD KLW) beschikbaar gesteld voor dit onderzoek. Voorafgaand aan het gebruik van de dataset voor onderzoeksdoeleinden heeft Wageningen Livestock Research (WLR) op verzoek van 
ZuiveINL een analyse uitgevoerd van de bruikbaarheid van de individuele records voor onderzoek in de volledige dataset. De aangeleverde data zijn getoetst aan de hand van een data-screeningsprotocol dat is ontwikkeld om bedrijven met onmogelijke en extreme waarden voor kengetallen te onderkennen en vervolgens de betreffende bedrijven uit te sluiten van opname in de onderzoeksdatasets. De datasets werden anoniem geleverd met alleen de vier cijferige postcode, dus zonder de twee letters. Op basis van de vier cijfers van de postcode zijn de bedrijven toegewezen aan een provincie. De postcode van de drie provincies zijn betrokken van de website postcode.site/nl.

Ten behoeve van analyses op grondsoort zijn data-subsets gemaakt voor de grondsoorten klei, veen en zand. In deze subsets zijn bedrijven opgenomen waar 100\% van het totale areaal behoorde tot één grondsoort (op basis van informatie uit de dataset van de KringloopWijzer). Op die manier ontstonden subsets met zuivere klei-, veen- en zandbedrijven, en een subset overig van bedrijven met meerdere grondsoorten.

In tabel 1 staan de kengetallen die zijn gebruikt voor het duiden van de mineralenprestaties in NoordNederland.

Tabel 1 Gebruikte kengetallen voor het duiden van de mineralenprestaties in Noord-Nederland.

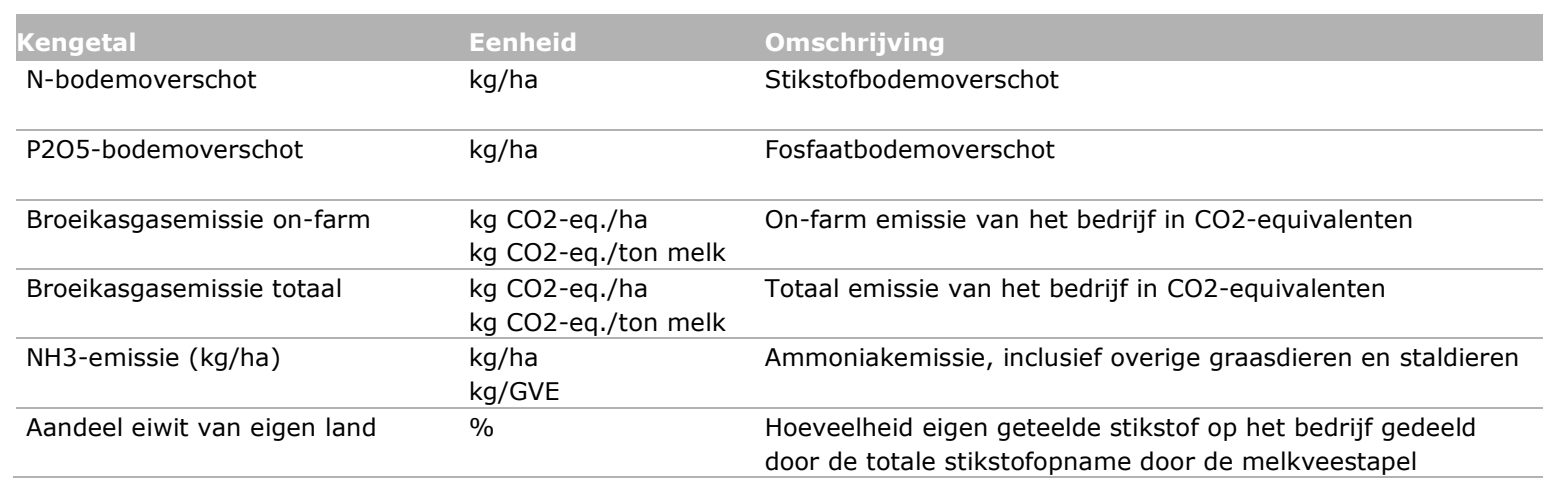

Naast de kengetallen om de mineralenprestaties te duiden zijn de volgende kengetallen gebruikt om de bedrijfsstructuur te duiden:

- Intensiteit (kg melk/ha)

- Oppervlakte (ha)

- Aandeel maisland (\%), ongewogen gemiddelde van alle bedrijven

- Aandeel klei (\%), ongewogen gemiddelde van alle bedrijven

- Aandeel veen (\%), ongewogen gemiddelde van alle bedrijven

- Aandeel zand (\%), ongewogen gemiddelde van alle bedrijven

- Melkproductie bedrijf (kg melk/bedrijf)

- Melkproductie per koe (kg melk/koe)

- Aantal koeien

- Aantal GVE per koe (gve/koe)

- Uren weidegang (uur)

Kengetallen zijn uitgedrukt per kg melk, en niet omgerekend naar kg meetmelk.

Om het effect van mineralisatie van veen op het stikstofbodemoverschot en broeikasgasemissie buiten beschouwing te kunnen laten zijn deze twee kengetallen ook berekend exclusief de bijdrage van de veenmineralisatie. De bijdrage van de mineralisatie van veen wordt als volgt door de KringloopWijzer berekend:

- In de KringloopWijzer wordt een waarde toegekend van $235 \mathrm{~kg} \mathrm{~N}$ per ha voor veenmineralisatie. Dit betreft alleen de hectares veengrond (Schröder et al., 2017; Schröder et al., 2018).

- De lachgasemissie die verbonden is aan de mineralisatie van veen wordt in de KringloopWijzer geschat op $2 \%$ van $235 \mathrm{~kg} \mathrm{~N}$, wat neerkomt op 4,7 kg N2O-N per ha veengrond. In de KringloopWijzer versies van 2016 en 2017 wordt een omrekenfactor van 265 kg CO2 per kg N2O-N gehanteerd o.b.v. de IPPC 2015 (Schröder et al., 2017; Schröder et al., 2018). 
In dit hoofdstuk wordt een overzicht gegeven van de bedrijfsstructuur van de melkveehouderij in Nederland en Noord-Nederland. Daarna wordt per kengetal besproken wat de behaalde resultaten zijn in 2016 en 2017 en worden deze vergeleken met het resultaat uit 2013. In bijlage 2 en 3 staan overzichten van de mineralenprestaties van 2016 en 2017 met daarin het gemiddelde en de spreiding van elk kengetal voor Nederland, Noord-Nederland, de drie Noordelijke provincies en per grondsoort. In bijlage 4 zijn de gemiddelde resultaten voor 2013, 2016 en 2017 in één tabel samengevat voor Nederland en Noord-Nederland. In bijlage 5 zijn de gemiddelde resultaten voor 2016 en 2017 in één tabel samengevat voor de drie Noordelijke provincies. En in bijlage 6 zijn de gemiddelde resultaten voor 2016 en 2017 per grondsoort in een tabel samengevat voor Nederland en Noord-Nederland.

\subsection{Bedrijfsstructur melkveehouderij}

In tabel 2 zijn de bedrijfskenmerken van de melkveehouderij van Nederland en Noord-Nederland gegeven o.b.v. resultaten uit de WEcR-studie uit 2015 (Daatselaar et al., 2015) en deze studie.

Tabel 2 Bedrijfsstructuur van de melkveehouderij in Nederland en Noord-Nederland.

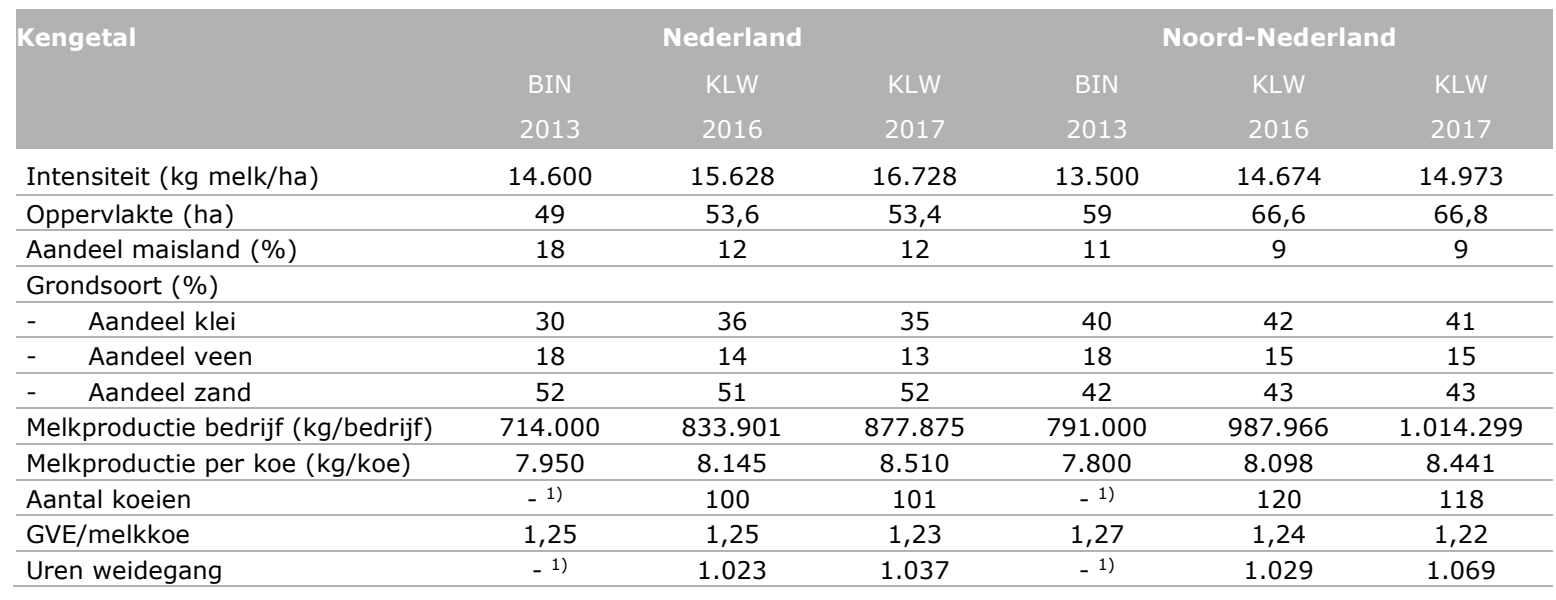

1) $=$ niet gerapporteerd.

De volgende verschillen in bedrijfsstructuur tussen Nederland en Noord-Nederland zijn zichtbaar:

- De melkproductie per ha in Noord-Nederland is lager dan in Nederland (-10\% in 2017).

- De melkproductie per ha in geheel Nederland is iets sterker gestegen $(+15 \%)$ dan in NoordNederland (+11\%), (2017 t.o.v. 2013), zie figuur 1

- In 2017 is in Nederland de gemiddelde melkproductie per ha met $1100 \mathrm{~kg} / \mathrm{ha}$ toegenomen, in Noord-Nederland is de toename met $300 \mathrm{~kg} / \mathrm{ha}$ duidelijk lager.

- Bedrijven in Noord-Nederland zijn gemiddeld groter in oppervlakte en in aantal koeien.

- Er heeft een duidelijke stijging van de melkproductie per koe plaatsgevonden, zowel in Nederland $(+7 \%)$ als in Noord-Nederland (+8\%), (2017 t.o.v. 2013). De productie per koe in NoordNederland is vrijwel gelijk aan de productie per koe in Nederland (-1\% in 2017).

- T.o.v. 2013 is het aantal GVE/koe in Noord-Nederland iets sterker gedaald dan in Nederland. In 2017 is het aantal GVE/koe in Nederland $(1,23)$ vrijwel gelijk aan het aantal in Noord-Nederland $(1,22)$, zie figuur 2 .

- Het aantal uren weidegang is vrijwel gelijk in Nederland en Noord-Nederland (ruim 1000 uur per jaar), maar lijkt in 2017 in Noord-Nederland iets meer toe te nemen dan in heel Nederland.

- Bedrijven in Noord-Nederland hebben gemiddeld een iets hoger aandeel klei en een lager aandeel zand dan bedrijven in heel Nederland, het aandeel veen is vrijwel gelijk. 

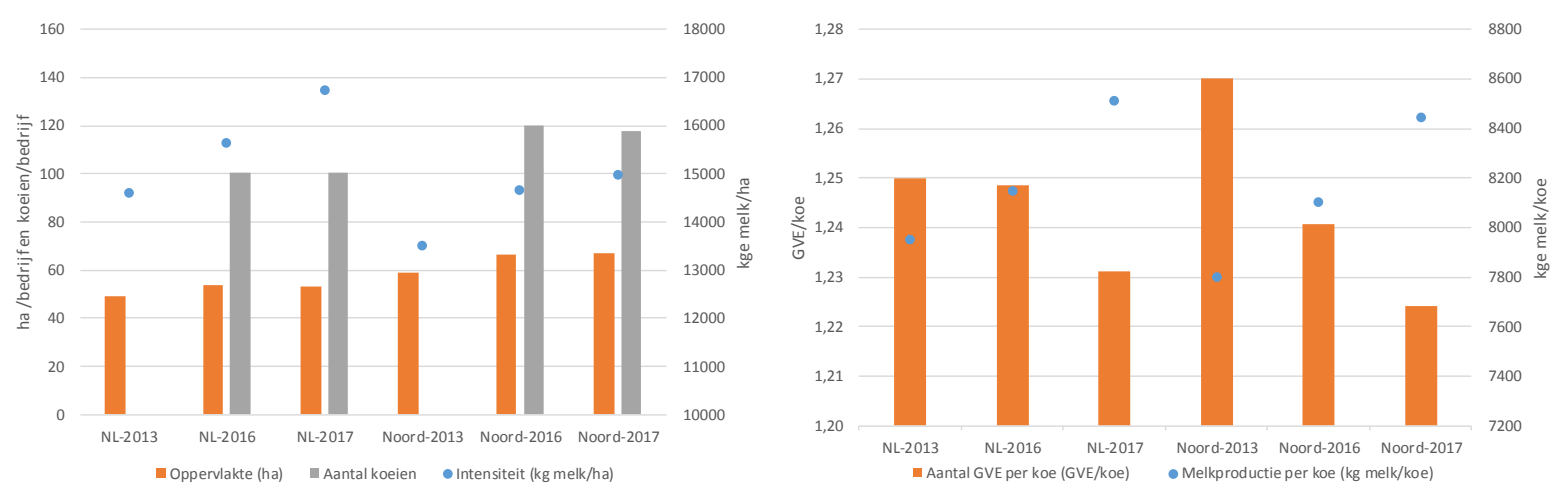

Figuur 1 Gemiddelde oppervlakte (linker verticale as), aantal koeien (linker verticale as) en bedrijfsintensiteit (rechter verticale as) (linker figuur) en gemiddeld aantal GVE per koe (linker verticale as) en melkproductie per koe (rechter verticale as) (rechter figuur) in Nederland en Noord-Nederland.

In tabel 3 zijn de bedrijfskenmerken van de melkveehouderij van de drie Noordelijke provincies weergegeven over de jaren 2016 en 2017.

Tabel 3 Bedrijfsstructuur van de melkveehouderij in Drenthe, Friesland en Groningen

\begin{tabular}{|c|c|c|c|c|c|c|}
\hline \multirow[t]{2}{*}{ Kengetal } & \multicolumn{2}{|c|}{ Drenthe } & \multicolumn{2}{|c|}{ Friesland } & \multicolumn{2}{|c|}{ Groningen } \\
\hline & 2016 & 2017 & 2016 & 2017 & 2016 & 2017 \\
\hline Intensiteit (kg melk/ha) & 14.571 & 15.312 & 14.819 & 14.880 & 14.317 & 14.886 \\
\hline Oppervlakte (ha) & 65,7 & 66,0 & 65,8 & 66,1 & 70,2 & 70,1 \\
\hline Aandeel maisland (\%) & 16 & 16 & 7 & 7 & 7 & 7 \\
\hline Aandeel veen & 10 & 9 & 20 & 20 & 4 & 6 \\
\hline - $\quad$ Aandeel zand & 88 & 89 & 33 & 33 & 26 & 23 \\
\hline Melkproductie bedrijf (kg/bedrijf) & 955.178 & 1.007 .538 & 989.297 & 1.001 .135 & 1.018 .838 & 1.065 .943 \\
\hline Melkproductie per koe (kg/koe) & 8.180 & 8.610 & 8.113 & 8.396 & 7.966 & 8.392 \\
\hline Aantal koeien & 115 & 114 & 120 & 117 & 125 & 124 \\
\hline
\end{tabular}

De gemiddelde bedrijfsintensiteit in de drie noordelijke provincies is vrijwel gelijk, zie figuur 2 . Ten opzichte van 2016 is de intensiteit in Friesland in 2017 vrijwel gelijk gebleven, bedrijven in Drenthe en Groningen zijn iets intensiever geworden. Het aandeel bedrijven op zandgrond en het aandeel maïsland op de bedrijven is in Drenthe duidelijk hoger dan in Friesland en Groningen. Bedrijven in Drenthe weiden duidelijk minder uren dan bedrijven in Friesland en Groningen. De jongveebezetting is in alle provincies gedaald. 


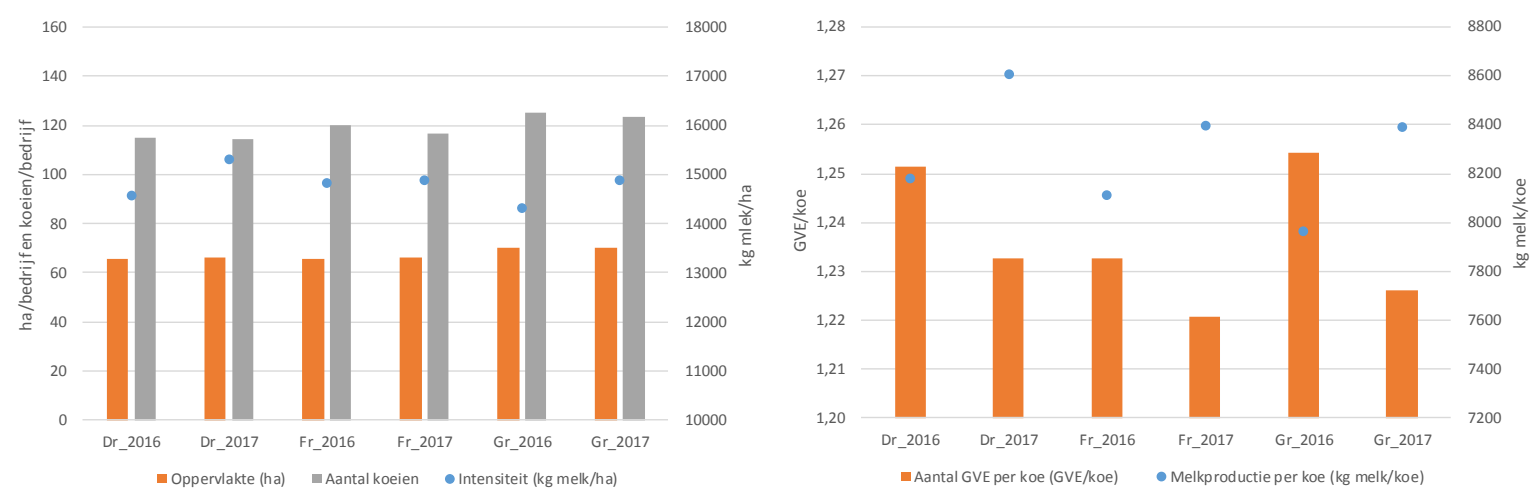

Figuur 2 Gemiddelde oppervlakte, aantal koeien (linker verticale as) en bedrijfsintensiteit (rechter verticale as) (linker figuur) en gemiddeld aantal GVE per koe (linker verticale as) en melkproductie per koe (rechter verticale as) (rechter figuur) in de drie Noordelijke provincies.

In tabellen 4 en 5 zijn de structuurcijfers van de melkveehouderij per grondsoort weergegeven over de jaren 2016 en 2017 voor respectievelijk Nederland en Noord-Nederland.

Tabel 4 Bedrijfsstructuur van de melkveehouderij in Nederland per grondsoort (100\% klei, 100\% veen, $100 \%$ zand en overig).

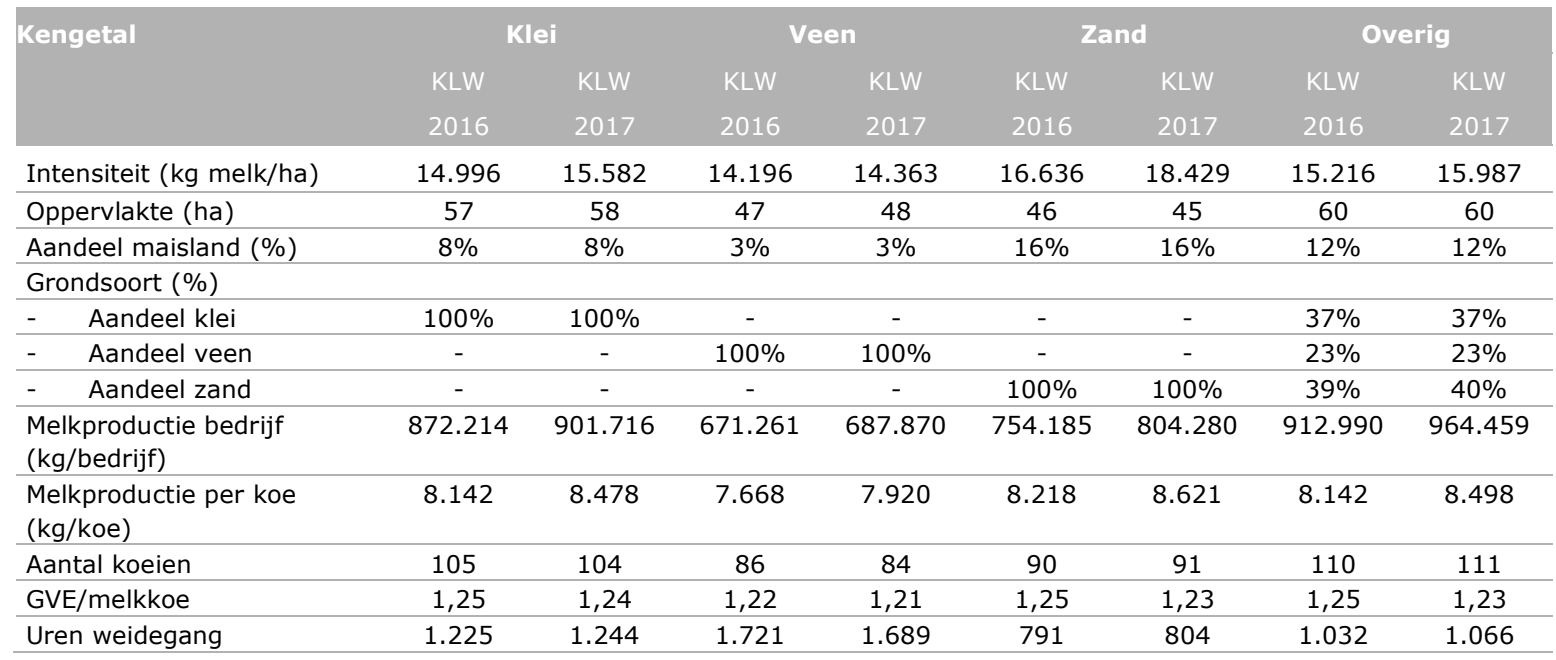

Tabel 5 Bedrijfsstructuur van de melkveehouderij in Noord-Nederland per grondsoort (100\% klei, $100 \%$ veen, $100 \%$ zand en overig).

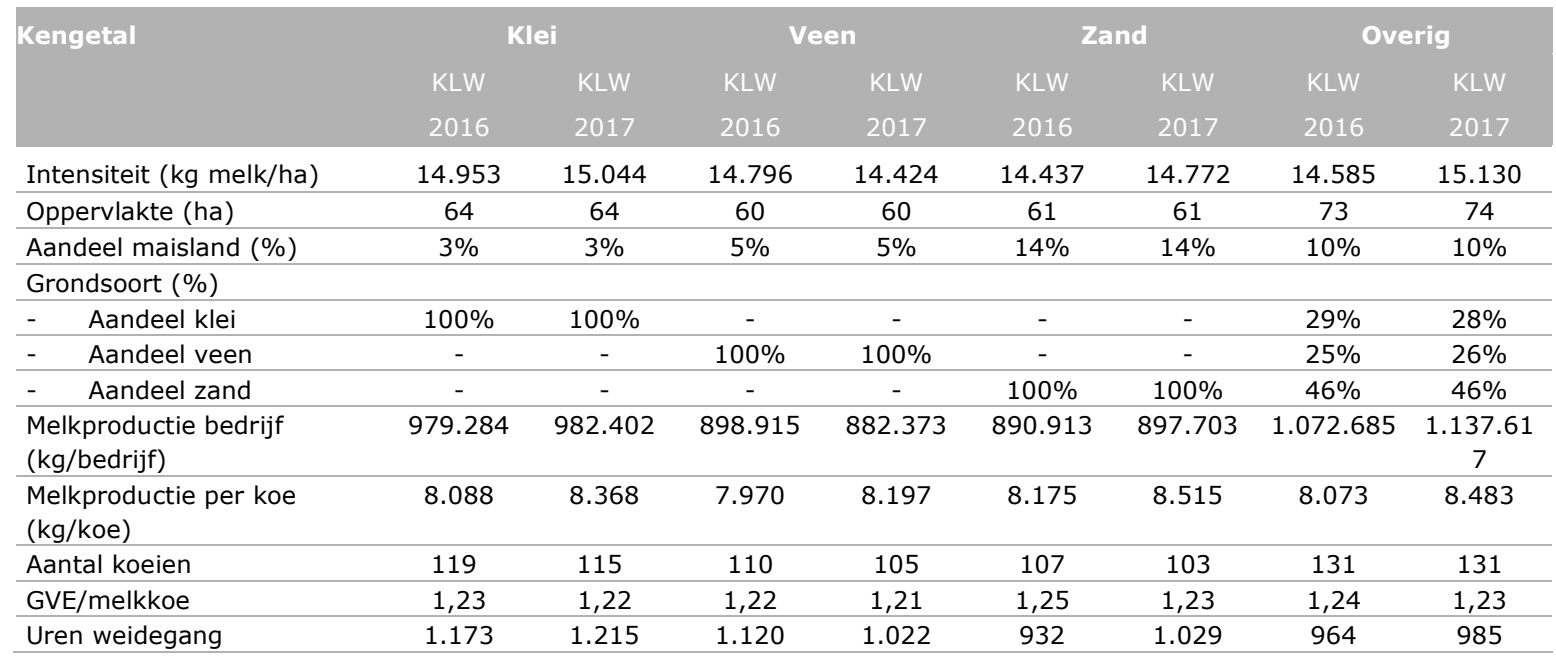


De gemiddelde intensiteit in Nederland is gestegen van 2016 naar 2017, vooral op zandgrond en in mindere mate op klei. Met name zandbedrijven in Noord-Nederland zijn minder intensief dan zandbedrijven in geheel Nederland. Bedrijven op veengrond in Nederland weiden veruit het meest (circa 1700 uren), bedrijven op veengrond in Noord-Nederland weiden duidelijk minder (circa 1100 uren). In 2017 is het aantal uren beweiding op veengrond gedaald, op overige grondsoorten is het aantal uren beweiding juist iets toegenomen, zowel in Noord-Nederland als heel Nederland. Het aandeel maïsland in Noord-Nederland is op alle grondsoorten lager dan in Nederland, behalve op veengrond. Bedrijven op veengrond in Noord-Nederland hebben juist meer maïsland dan bedrijven op veengrond in geheel Nederland.

\subsection{Stikstof- en fosfaatbodemoverschot}

In figuren 3 en 4 staan het gemiddelde stikstof- (inclusief en exclusief veenmineralisatie) en fosfaatbodemoverschot weergegeven voor 2013, 2016 en 2017 voor Nederland, Noord-Nederland en de drie Noordelijke provincies. In bijlage 6 staan de resultaten per grondsoort weergegeven voor Nederland en Noord-Nederland.
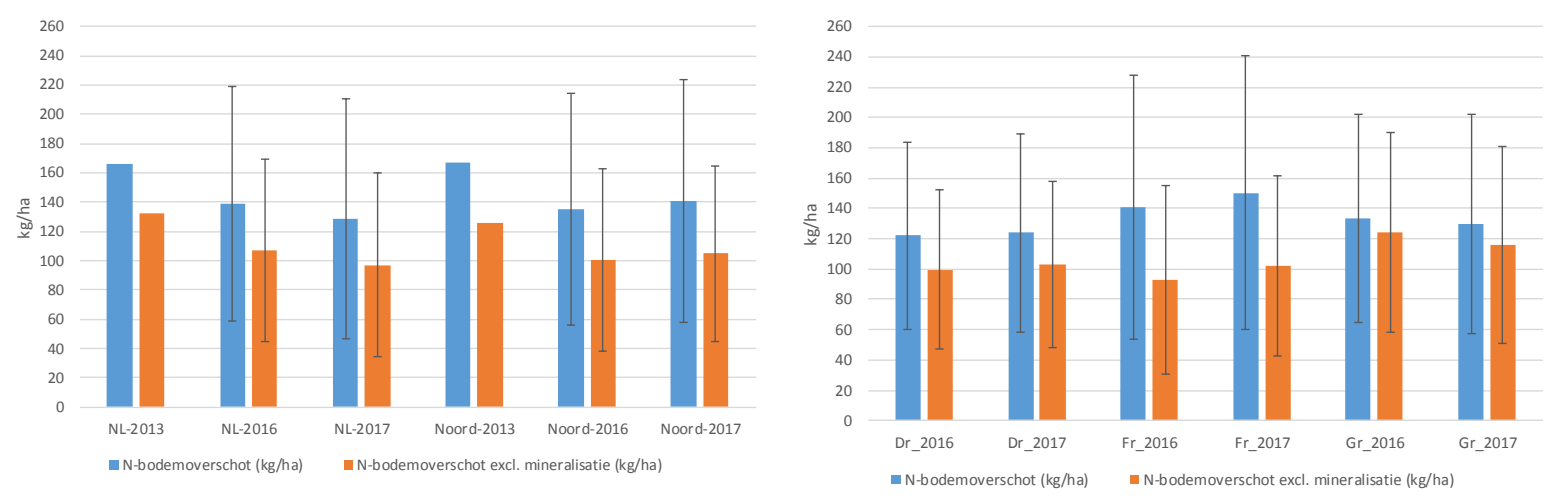

Figuur 3 Gemiddeld stikstofbodemoverschot ( $\mathrm{kg} / \mathrm{ha}$ ) met standaarddeviatie ( $\pm 1 \mathrm{SD}$ ) voor Nederland en Noord-Nederland (links) en voor de drie Noordelijke provincies (rechts).
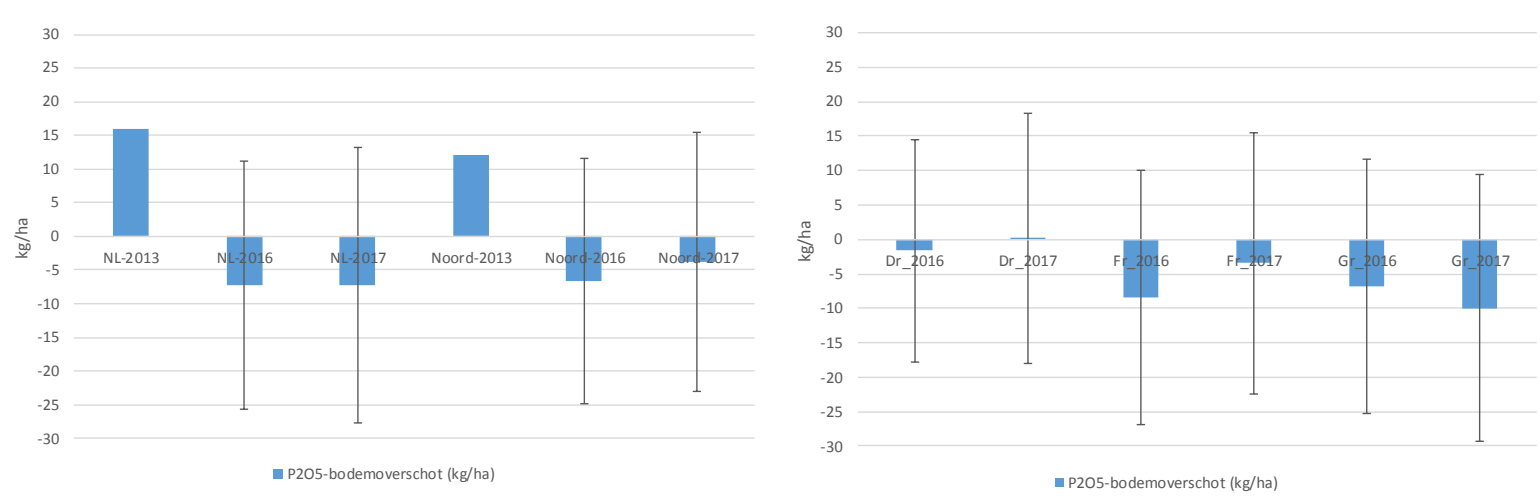

Figur 4 Gemiddeld fosfaatbodemoverschot ( $\mathrm{kg} / \mathrm{ha}$ ) met standaarddeviatie ( \pm 1 SD) voor Nederland en Noord-Nederland (links) en voor de drie Noordelijke provincies (rechts).

De resultaten van de bodemoverschotten laten het volgende beeld zien:

- Het stikstofbodemoverschot was in 2016 en 2017 duidelijk lager dan in 2013, zowel in Nederland als Noord-Nederland.

- Het stikstofbodemoverschot was in Nederland in 2017 iets lager dan in 2016, en in Noord-Nederland juist iets hoger (vooral in Friesland).

- Het fosfaatbodemoverschot is gedaald t.o.v. 2013, zowel in Nederland als Noord-Nederland

- Het fosfaatbodemoverschot was in Nederland in 2017 gelijk aan 2016, en in Noord-Nederland iets hoger (minder negatief).

- De variatie in bodemoverschot tussen bedrijven is groot, wat zichtbaar is in een hoge standaarddeviatie. 
Opvallend is dat het N-bodemoverschot in Noord-Nederland in 2016 iets hoger is dan in 2017, terwijl dit in heel Nederland juist andersom is. Dit doet zich voor op alle grondsoorten. Een vergelijkbaar effect is te zien in P2O5-bodemoverschot.

\subsection{Broeikasgasemissie}

In figuren 5 en 6 staan de broeikasgasemissies (on-farm en totaal) weergegeven voor 2013, 2016 en 2017 voor Nederland, Noord-Nederland en drie Noordelijke provincies. In bijlage 6 staan de resultaten per grondsoort weergegeven voor Nederland en Noord-Nederland.
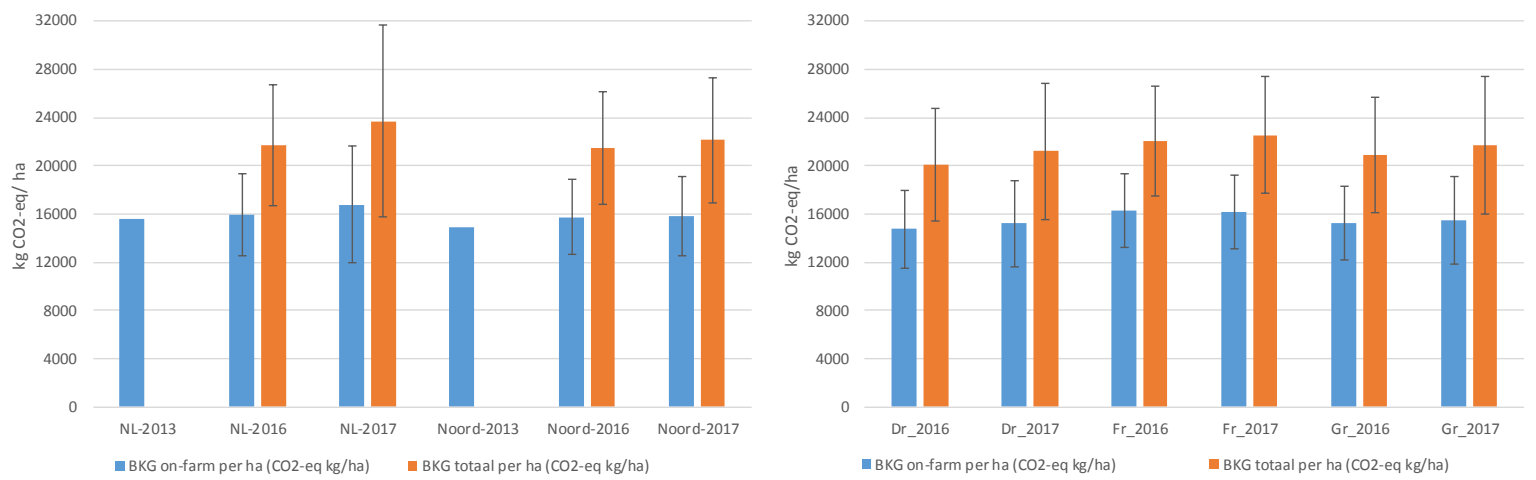

Figur 5 Gemiddelde broeikasgasemissie (kg CO2-eq. per ha) met standaarddeviatie ( \pm 1 SD) voor Nederland en Noord-Nederland (links) en de drie Noordelijke provincies (rechts).
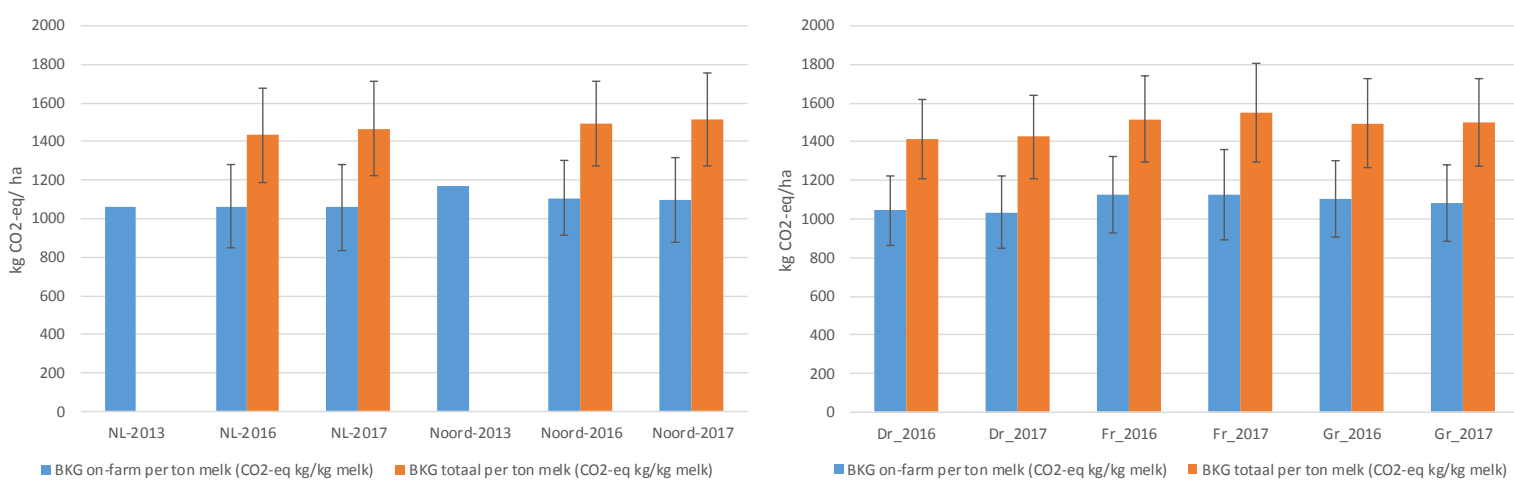

Figurr 6 Gemiddelde broeikasgasemissie ( $k g$ CO2-eq. per ton melk) met standaarddeviatie ( \pm 1 SD) voor Nederland en Noord-Nederland (links) en de drie Noordelijke provincies (rechts).

De resultaten van de broeikasgasemissies laten het volgende beeld zien:

- De on-farm broeikasgasemissie per hectare in Nederland was in 2017 8\% hoger dan in 2013, en in Noord-Nederland 7\% hoger.

- De on-farm broeikasgasemissie per ton melk in Nederland is in 2017 niet veranderd t.o.v. 2013, en in Noord-Nederland met 6\% gedaald.

- De totale broeikasgasemissie per ton melk in Nederland is in 2017 met 2\% gedaald t.o.v. 2013, en in Noord-Nederland met $7 \%$ gedaald.

- De on-farm en totale broeikasgasemissie per ha in Noord-Nederland waren in 2017 circa 6\% lager dan in Nederland.

- De on-farm en totaal broeikasgasemissie per ton melk waren in Noord-Nederland in 2017 circa $4 \%$ hoger dan in Nederland.

- De broeikasgasemissie per ton melk was van de Noordelijke provincies het laagst in Drenthe, en het hoogst in Friesland. De toename in 2017 was het grootst in Friesland. 


\subsection{Ammoniakemissie}

In figuur 7 staat de ammoniakemissie weergegeven voor 2013, 2016 en 2017 voor Nederland, NoordNederland en drie Noordelijke provincies. In bijlage 6 staan de resultaten per grondsoort weergegeven voor Nederland en Noord-Nederland.
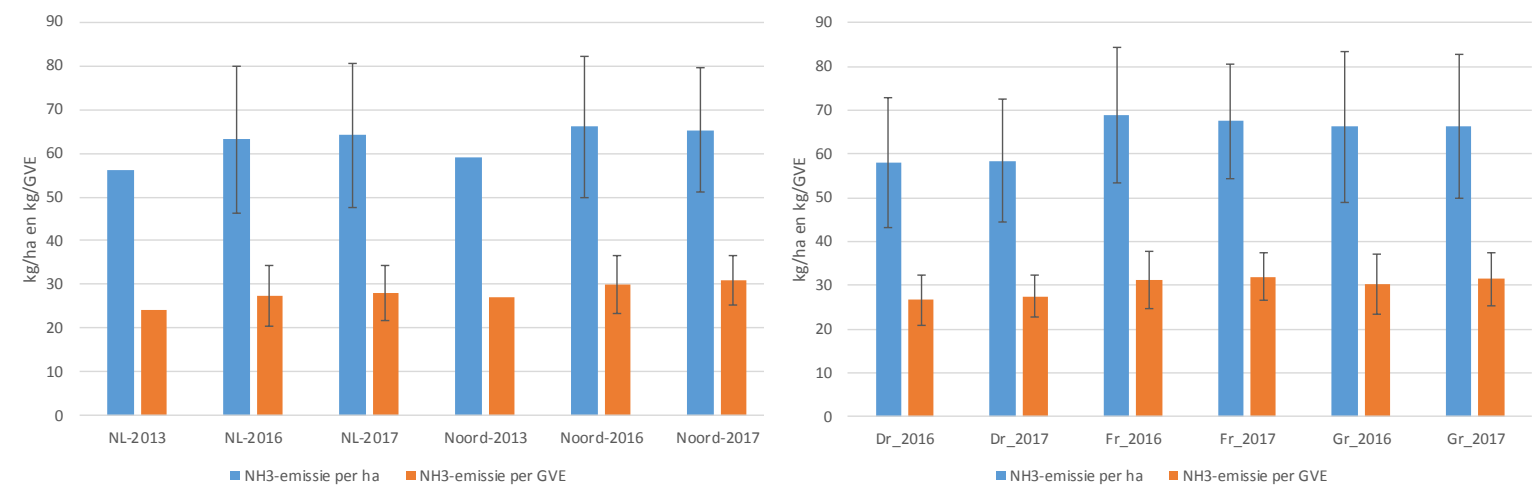

Figur $7 \quad$ Gemiddelde ammoniakemissie ( $k g$ per ha en $\mathrm{kg}$ per GVE) met standaarddeviatie ( $\pm 1 S D$ ) voor Nederland en Noord-Nederland (links) en de drie Noordelijke provincies (rechts).

De resultaten van de ammoniakemissie laten het volgende beeld zien:

- De ammoniakemissie per ha is gestegen t.o.v. 2013, zowel in Nederland als Noord-Nederland.

- Een lichte stijging van de ammoniakemissie in 2017 in Nederland t.o.v. 2016, en een lichte daling in Noord-Nederland (vooral Friesland). Daardoor wordt het verschil tussen Nederland en NoordNederland kleiner. In 2013 is de emissie per ha in Noord-Nederland 5\% hoger dan in Nederland, en in 2017 nog $2 \%$.

- De ammoniakemissie per GVE is gestegen t.o.v. 2013, zowel in Nederland als in Noord-Nederland. Het verschil in ammoniakemissie tussen Noord-Nederland en Nederland was in 2017 iets kleiner $(+10 \%)$ dan in $2013(+13 \%)$.

\subsection{Eiwit van eigen land}

In figuur 8 staat het percentage eiwit van eigen land weergegeven voor 2013, 2016 en 2017 voor Nederland en Noord-Nederland en drie Noordelijke provincies. In bijlage 6 staan de resultaten per grondsoort weergegeven voor Nederland en Noord-Nederland.
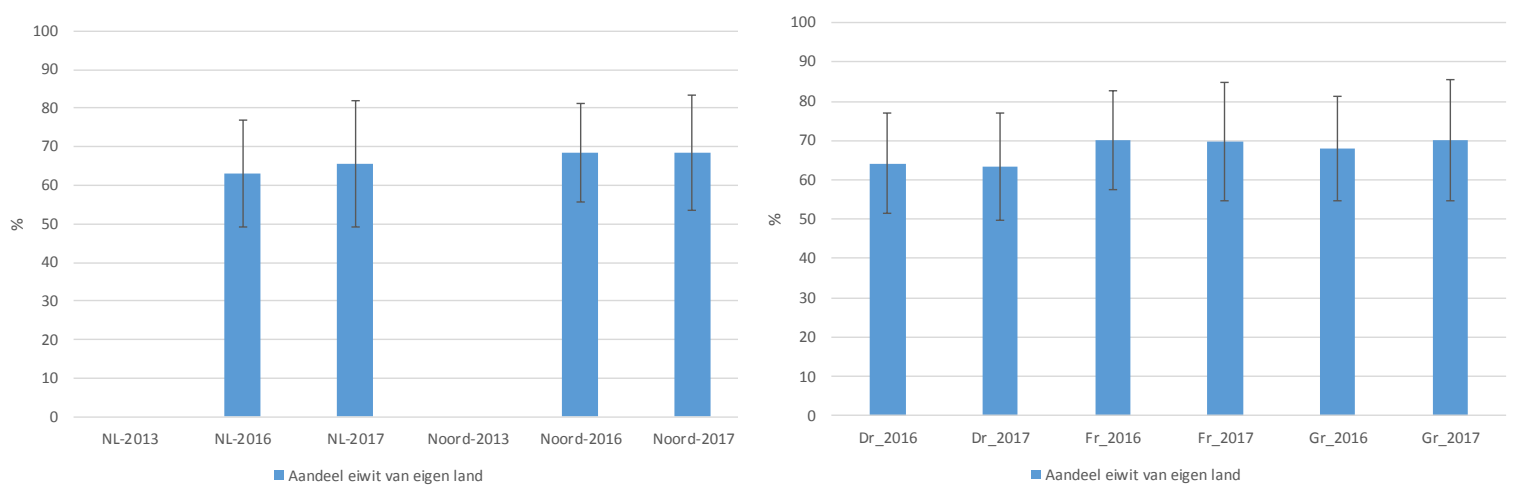

Figur 8 Gemiddeld percentage eiwit van eigen land (\%) met standaarddeviatie ( \pm 1 SD) voor Nederland en Noord-Nederland (links) (over 2013 zijn geen resultaten beschikbaar) en de drie Noordelijke provincies (rechts). 
In 2017 was het gemiddeld aandeel eiwit van eigen land in Nederland 65,6\%. Dat is 2,5\% hoger dan in 2016. In Noord-Nederland bleef het aandeel eiwit van eigen land gelijk (68,5\%). In Noord Nederland is het aandeel eiwit van eigen land hoger dan gemiddeld in Nederland. Gemiddeld wordt de grondgebondenheidseis van $65 \%$ in Noord-Nederland gehaald.

\subsection{Resultaten van de $25 \%$ best scorende bedrijven in Noord-Nederland}

Op basis van de resultaten van de 25\% best-presterende bedrijven in 2013 zijn door WEcR streefwaarden opgesteld voor vier duurzaamheidsindicatoren: stikstofbodemoverschot, fosfaatbodemoverschot, broeikasgasemissie en ammoniakemissie (Daatselaar et al., 2015). Op grond van o.a. deze streefwaarden heeft de Versnellingsagenda melkveehouderij Noord-Nederland voor deze kengetallen doelwaarden voor 2020 geformuleerd (Greenlincs, 2015). In tabel 6 zijn voor deze kengetallen de geformuleerde streef- en doelwaarden weergegeven.

Tabel 6 Geformuleerde streef- en doelwaarden voor de gebruikte kengetallen om de mineralenprestaties van de melkveebedrijven in Noord-Nederland te duiden (Daatselaar et al., 2015; Greenlincs, 2015).

\begin{tabular}{|c|c|c|}
\hline Kengetal & WECR & Versnellingsagenda \\
\hline $\mathrm{N}$-bodemoverschot & $\begin{array}{l}\text { Voor klei- en zandregio circa } 125 \mathrm{~kg} \mathrm{~N} / \mathrm{ha} \text {. } \\
\text { Voor veenregio circa } 75 \mathrm{~kg} \mathrm{~N} / \mathrm{ha} \text { waarbij } \\
\text { de mineralisatie niet is meegenomen. }\end{array}$ & $\begin{array}{l}\text { Voor klei- en zandregio ca. } 125 \mathrm{~kg} \mathrm{~N} / \mathrm{ha} . \\
\text { Voor veenregio ca. } 75 \mathrm{~kg} \mathrm{~N} / \mathrm{ha} \text { hier } \\
\text { mineralisatie niet meenemen. }\end{array}$ \\
\hline P2O5-bodemoverschot & $\begin{array}{l}0 \mathrm{~kg} \text { P205/ha, eventueel gedifferentieerd } \\
\text { naar fosfaattoestand van de bodem. }\end{array}$ & $\begin{array}{l}0 \mathrm{~kg} \text { fosfaat/ha voor fosfaattoestand } \\
\text { neutraal. }\end{array}$ \\
\hline Broeikasgasemissie on-farm & $\begin{array}{l}\text { Voor klei- en zandregio } 900 \text { tot } 1000 \mathrm{~kg} \\
\text { CO2-equivalent per ton melk. } \\
\text { Voor veenregio hetzelfde, maar emissie } \\
\text { lachgas niet meenemen. }\end{array}$ & - \\
\hline Broeikasgasemissie totaal & - & $\begin{array}{l}20 \% \text { reductie van broeikasgassen in } 2020 \\
\text { ten opzichte van } 1990 \text {, inclusief } \\
\text { klimaatneutrale groei. }\end{array}$ \\
\hline NH3-emissie (kg/ha) & $50 \mathrm{~kg} / \mathrm{ha}$ of $25 \mathrm{~kg} / \mathrm{GVE}$. & $\begin{array}{l}25 \mathrm{~kg} / \mathrm{GVE} \text { op klei en veen. } \\
20 \mathrm{~kg} / \mathrm{GVE} \text { op zand. }\end{array}$ \\
\hline
\end{tabular}

Hiernaast heeft de Commissie Grondgebondenheid in 2018 het advies gegeven dat in 2025 minimaal $65 \%$ van de eiwitbehoefte op het melkveebedrijven moet afkomstig zijn van eigen grond, inclusief buurtcontracten (CG, 2018).

In tabel 7 staat het gemiddelde van de $25 \%$ best scorende bedrijven in Noord-Nederland per kengetal weergegeven. Tevens is het $25 \%$ kwartiel weergegeven wat aangeeft wat de boven- of ondergrens van deze $25 \%$ best scorende bedrijven per kengetal is, oftewel alle $25 \%$ best scorende bedrijven behalen een resultaat gelijk aan dit getal of beter. Ook is het $50 \%$ kwartiel opgenomen wat aangeeft dat de helft van de bedrijven een resultaat halen gelijk aan dit getal of beter. 
Tabel 7 Gemiddelde warde van de $25 \%$ best scorende bedrijven in Noord-Nederland per kengetal en de $25 \%$ en $50 \%$ kwartielen.

\begin{tabular}{|c|c|c|c|c|c|c|}
\hline \multirow[t]{2}{*}{ Kengetal } & \multicolumn{3}{|c|}{2016} & \multicolumn{3}{|c|}{2017} \\
\hline & beste & kwartiel & kwartiel & beste & kwartiel & kwartiel \\
\hline N-bodemoverschot (kg/ha) & 46 & 84 & 125 & 48 & 90 & 131 \\
\hline N-bodemoverschot excl. veenmineralisatie (kg/ha) & 23 & 63 & 101 & 28 & 70 & 109 \\
\hline P205-bodemoverschot (kg/ha) & -29 & -18 & -6 & -28 & -15 & -3 \\
\hline Broeikasgasemissie totaal (kg CO2-eq./ha) & 15.698 & 18.589 & 21.329 & 16.097 & 19.130 & 21.942 \\
\hline Broeikasgasemissie on-farm (kg CO2-eq./ton melk) & 921 & 979 & 1.063 & 900 & 963 & 1.050 \\
\hline Broeikasgasemissie totaal (kg CO2-eq./ton melk) & 1.277 & 1.350 & 1.449 & 1.288 & 1.365 & 1.470 \\
\hline NH3-emissie $(\mathrm{kg} / \mathrm{ha})$ & 46,9 & 56,8 & 65,9 & 48,0 & 56,9 & 65,2 \\
\hline NH3-emissie (kg/GVE) & 22,7 & 26,2 & 29,6 & 24,6 & 27,4 & 30,5 \\
\hline Aandeel eiwit van eigen land (\%) & 84 & 77 & 69 & 87 & 77 & 67 \\
\hline
\end{tabular}

De resultaten van de $25 \%$ best presterende bedrijven per kengetal laten het volgende beeld zien voor zowel 2016 als 2017:

- De $25 \%$ best presterende bedrijven op het kengetal stikstofbodemoverschot (excl.

veenmineralisatie) voldoen aan de doelwaarde van maximaal van 125 en $75 \mathrm{~kg}$ N/ha voor respectievelijk klei/zand en veen. Meer dan de helft van bedrijven voldoet aan de doelwaarde van maximaal $125 \mathrm{~kg} \mathrm{~N} / \mathrm{ha}$.

- De $25 \%$ best presterende bedrijven op het kengetal fosfaatbodemoverschot voldoen aan de doelwaarde van maximaal $0 \mathrm{~kg}$ P205/ha. Meer dan de helft van de bedrijven voldoet hieraan.

- De $25 \%$ best presterende bedrijven op het kengetal broeikasgasemissie on-farm realiseren de streefwaarde van maximaal $1000 \mathrm{~kg} \mathrm{CO2-eq.} \mathrm{per} \mathrm{ton} \mathrm{melk.} \mathrm{Minder} \mathrm{dan} \mathrm{de} \mathrm{helft} \mathrm{van} \mathrm{de} \mathrm{bedrijven}$ haalt dit doel.

- De $25 \%$ best presterende bedrijven op het kengetal ammoniakemissie realiseren gemiddeld 46,9 kg $\mathrm{NH} 3$ per ha en 22,7 kg NH3 per GVE. Daarmee voldoen ze gemiddeld aan de streefwaarde van 50 $\mathrm{kg} \mathrm{NH3}$ per ha en $25 \mathrm{~kg} / \mathrm{GVE}$. De $25 \%$ kwartiel waarde ligt echter boven de doelwaarde, wat betekent dat niet alle bedrijven in deze groep de doelwaarde realiseren. Minder dan een kwart van de bedrijven voldoet aan de doelwaarde voor ammoniakemissie.

- De $25 \%$ best presterende bedrijven op het kengetal eiwit van eigen land halen ruim meer dan $65 \%$ van hun eiwitbehoefte van eigen land. Meer dan de helft van de bedrijven haalt dit doel. Overigens is dit nog zonder rekening houden met buurtcontracten.

Om meer inzicht te krijgen hoe bedrijven overall scoren is voor de $25 \%$ best scorende bedrijven op het kengetal stikstofbodemoverschot (exclusief veenmineralisatie) nagegaan hoe zij scoren op de andere kengetallen. In tabellen 8 staan het gemiddelde van alle kengetallen van de $25 \%$ best scorende bedrijven in Noord-Nederland op het kengetal N-bodemoverschot weergegeven over 2016 en 2017. En in tabellen 9 en 10 is dit per grondsoort weergegeven over 2016 en 2017.

Tabel 8 Gemiddelde resultaten van 25\% best scorende bedrijven op het kengetal Nbodemoverschot excl. veenmineralisatie en gemiddelde van alle bedrijven in NoordNederland over 2016 en 2017.

\begin{tabular}{|c|c|c|c|c|}
\hline Kengetal & \multicolumn{2}{|c|}{2016} & \multicolumn{2}{|c|}{2017} \\
\hline N-bodemoverschot (kg/ha) & 86 & 135 & 83 & 141 \\
\hline P2O5-bodemoverschot (kg/ha) & -20 & -7 & -18 & -4 \\
\hline Broeikasgasemissie on-farm (kg CO2-eq./ha) & 16.455 & 15.765 & 16.264 & 15.865 \\
\hline Broeikasgasemissie totaal (kg CO2-eq./ton melk) & 1.532 & 1.492 & 1.532 & 1.515 \\
\hline NH3-emissie $(\mathrm{kg} / \mathrm{ha})$ & 69,6 & 66,1 & 65,5 & 65,3 \\
\hline NH3-emissie (kg/GVE) & 31,1 & 30,0 & 30,7 & 30,9 \\
\hline Aandeel eiwit van eigen land (\%) & 76 & 68 & 79 & 69 \\
\hline
\end{tabular}


De gemiddelde resultaten van de $25 \%$ best presterende bedrijven in Noord-Nederland op het kengetal stikstofbodemoverschot exclusief veenmineralisatie laten voor de andere kengetallen het volgende beeld zien:

- Ze voldoen aan de doelwaarde voor fosfaatbodemoverschot van maximaal $0 \mathrm{~kg} \mathrm{P205/ha.}$

- Ze realiseren een hogere on-farm broeikasgasemissie dan de streefwaarden van maximaal $1000 \mathrm{~kg}$ CO2-eq. per ton melk.

- Ze realiseren een hogere ammoniakemissie dan de streefwaarde van maximaal $50 \mathrm{~kg} / \mathrm{ha}$ en 25 $\mathrm{kg} / \mathrm{GVE}$ voor klei en veen, $20 \mathrm{~kg} / \mathrm{GVE}$ voor zand

- Ze halen ruim meer dan $65 \%$ van hun eiwitbehoefte van eigen land.

De $25 \%$ bedrijven met het laagste $\mathrm{N}$-bodemoverschot hebben ook een lager fosfaatbodemoverschot dan gemiddeld. Het aandeel eiwit van eigen land is hoger en de broeikasgas- en ammoniakemissies zijn gelijk of iets hoger dan gemiddeld.

De gemiddelde bedrijfsintensiteit op de $25 \%$ best presterende bedrijven voor stikstofbodemoverschot in 2016 en 2017 is respectievelijk $14.559 \mathrm{~kg}$ en $15.048 \mathrm{~kg}$ melk/ha. Dit is niet afwijkend van het gemiddelde over alle bedrijven (14.678 en $14.973 \mathrm{~kg}$ melk/ha). Ook de gemiddelde melkproductie per koe op de $25 \%$ best presterende bedrijven is niet afwijkend van het gemiddelde over alle bedrijven.

Omdat grondsoort effect kan hebben op de resultaten zijn de $25 \%$ best presterende bedrijven ook per grondsoort weergegeven (tabel 9 en 10).

Tabel 9 Gemiddelde resultaten van 25\% best scorende bedrijven op het kengetal $N$ bodemoverschot excl. veenmineralisatie en gemiddelde van alle bedrijven per grondsoort over 2016.

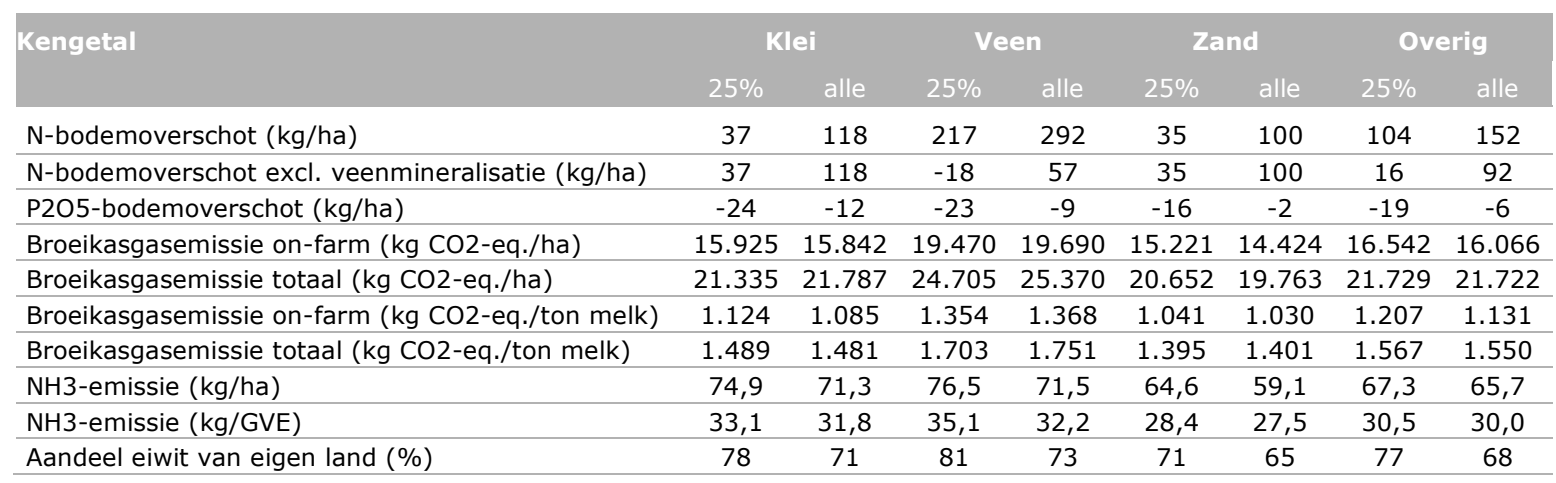

Tabel 10 Gemiddelde resultaten van 25\% best scorende bedrijven op het kengetal Nbodemoverschot excl. veenmineralisatie en gemiddelde van alle bedrijven per grondsoort over 2017.

\begin{tabular}{|c|c|c|c|c|c|c|c|c|}
\hline Kengetal & \multicolumn{2}{|c|}{ Klei } & \multicolumn{2}{|c|}{ Veen } & \multicolumn{2}{|c|}{ Zand } & \multicolumn{2}{|c|}{ Overig } \\
\hline N-bodemoverschot (kg/ha) & 36 & 117 & 222 & 308 & 37 & 105 & 102 & 160 \\
\hline N-bodemoverschot excl. veenmineralisatie (kg/ha) & 36 & 117 & -13 & 73 & 37 & 105 & 22 & 99 \\
\hline P2O5-bodemoverschot (kg/ha) & -25 & -10 & -22 & -2 & -15 & 1 & -16 & -3 \\
\hline Broeikasgasemissie on-farm (kg CO2-eq./ha) & 15.636 & 15.675 & 18.772 & 19.196 & 14.973 & 14.627 & 16.830 & 16.380 \\
\hline Broeikasgasemissie totaal (kg CO2-eq./ton melk) & 1.477 & 1.497 & 1.807 & 1.806 & 1.414 & 1.424 & 1.583 & 1.550 \\
\hline NH3-emissie $(\mathrm{kg} / \mathrm{ha})$ & 71,4 & 70,9 & 68,1 & 68,8 & 59,0 & 58,3 & 65,3 & 65,2 \\
\hline NH3-emissie (kg/GVE) & 33,3 & 33,2 & 33,3 & 33,0 & 27,4 & 28,1 & 30,5 & 30,7 \\
\hline Aandeel eiwit van eigen land (\%) & 83 & 72 & 87 & 72 & 75 & 64 & 78 & 68 \\
\hline
\end{tabular}

De resultaten van de $25 \%$ best presterende bedrijven per grondsoort op het kengetal stikstofbodemoverschot (exclusief veenmineralisatie) laten het volgende beeld zien:

- Ze voldoen aan de doelwaarde voor fosfaatbodemoverschot van maximaal $0 \mathrm{~kg} \mathrm{P205/ha.}$ 
- Ze realiseren een hogere on-farm broeikasgasemissie dan de streefwaarde van maximaal $1000 \mathrm{~kg}$ CO2-eq. per ton melk.

- Ze realiseren een hogere ammoniakemissie dan de streefwaarde van maximaal $50 \mathrm{~kg} / \mathrm{ha}$ en doelen van $25 \mathrm{~kg} / \mathrm{GVE}$ voor klei en veen, $20 \mathrm{~kg} / \mathrm{GVE}$ voor zand.

- Ze halen ruim meer dan $65 \%$ van hun eiwitbehoefte van eigen land.

Op alle grondsoorten realiseren de $25 \%$ best presterende bedrijven op het kengetal stikstofbodemoverschot een lager fosfaatbodemoverschot en een hoger aandeel eiwit van eigen land dan gemiddeld.

De broeikasgasemissies per ha lijken vooral op zandgrond in 2016 iets hoger voor de $25 \%$ bedrijven met het laagste stikstofbodemoverschot, op klei- en veengrond hebben de $25 \%$ bedrijven met het laagste stikstofbodemoverschot een vergelijkbare broeikasgasemissie per ha als gemiddeld. De broeikasgasemissies per ton melk zijn binnen grondsoorten niet duidelijk anders voor de $25 \%$ best presterende bedrijven op stikstofbodemoverschot dan voor het gemiddelde van alle bedrijven.

De ammoniakemissie op de $25 \%$ best presterende bedrijven op bodemoverschot in 2016 is op alle grondsoorten iets hoger dan gemiddeld. In 2017 liggen de resultaten dicht bij elkaar. Opvallend is dat de $25 \%$ best presterende bedrijven in 2017 een hoger aandeel eiwit van eigen land produceren dan in 2016, terwijl dit gemiddeld over alle bedrijven niet zo is.

De $25 \%$ best presterende bedrijven voor stikstofbodemoverschot hebben een vergelijkbare bedrijfsintensiteit als gemiddeld op de betreffende grondsoort. Alleen op zandgrond lijkt in 2016 de intensiteit op de $25 \%$ bedrijven met het laagste stikstofbodemoverschot iets hoger dan gemiddeld (+700 kg melk/ha). Dit kan een verklaring zijn voor de iets hoger broeikasgasemissie per ha. 


\section{Discussie}

\section{Vergelijkbaarheid tussen jaren}

De KringloopWijzerresultaten zijn berekend met verschillende versies van de KringloopWijzer (2015, 2016 en 2017 versie). Door aanpassingen in rekenmethodiek en standaarden in de onderliggende modules van de KringloopWijzer kan het resultaat van het ene jaar afwijken van het andere jaar, los van verschillen in bedrijfsvoering. Om een zuivere vergelijking te kunnen maken en alleen het effect van de bedrijfsvoering te kunnen inschatten, dienen de vergelijkingsjaren met dezelfde versie van KringloopWijzer te worden berekend. Echter dit is (nog) niet mogelijk met de gegevens van de KringloopWijzer in de Centrale Database KringloopWijzer (CD KLW).

De groep bedrijven in de KringloopWijzer-datasets is gedeeltelijk verschillend tussen 2016 en 2017. Bij kleine groepen bedrijven, zoals bij veengrond, kan dit mogelijk van invloed zijn op het gemiddelde resultaat. De verdeling over grondsoorten in de groep BIN-bedrijven (2013) en KringloopWijzer datasets was redelijk vergelijkbaar. Het gemiddelde aandeel veen in de groep BIN-bedrijven is iets hoger, het aandeel klei iets lager.

\section{Vergelijkbaarheid met andere kengetallen}

De berekende broeikasgasemissie uit de Centrale Database KringloopWijzer is niet gealloceerd naar melkproductie en zijn daardoor niet vergelijkbaar met de rekenwijze zoals die door zuivelondernemingen wordt gehanteerd in het samenwerkingsverband 'duurzame zuivelketen'.

\section{Jaarinvloeden}

Vanaf 2013 zijn er enkele wijzigingen in het mestbeleid doorgevoerd. De belangrijkste zijn de verlaging van de gebruiksnorm voor mest in 2014 van 250 naar 230 kg stikstof uit dierlijke mest voor de zuidelijke en oostelijke zandgronden. Daarnaast geldt het verbod op gebruik van fosfaatkunstmest op derogatiebedrijven sinds 2014. Hierdoor is vooral de fosfaatbemesting en daarmee het fosfaatbodemoverschot gedaald. De daling is verder versterkt door de lagere fosfaatgehalten in de mest als gevolg van maatregelen in de voeding om de fosfaatexcretie te verlagen.

Door weersinvloeden kunnen gewasopbrengsten van jaar tot jaar variëren. Doordat gewasopbrengsten mede bepalend zijn voor het bodemoverschot, variëren ook het stikstof- en fosfaatbodemoverschot tussen jaren. Het jaar 2013, het uitgangsjaar in deze studie, was geen gunstig jaar voor gewasgroei (Hilhorst et al., 2018), waardoor de bodemoverschotten dat jaar relatief hoog waren.

\section{Mogelijke oorzaken van effecten en verschillen}

In deze studie is gekeken naar mineralenprestaties van verschillende groepen bedrijven in verschillende jaren. Om prestaties en ontwikkelingen goed te kunnen verklaren is meer informatie nodig over met name opbrengst en bemesting van gras en snijmaïs en van rantsoensamenstelling. Maar mogelijk hebben, naast de jaarseffecten, zowel een beter mineralenmanagement als sturing van overheid en sector (gebruiksnormen, fosfaatreductieplan) geleid tot betere mineralenprestaties.

Vergeleken met 2013 is de emissie per ha van broeikasgassen en ammoniak toegenomen. Dit kan goed verklaard worden uit de gestegen melkproductie per ha. De gestegen melkproductie per koe is een logische verklaring voor de gestegen ammoniakemissie per GVE en de afgenomen broeikasgasemissie per ton melk. Ook in de rest van Nederland stegen de productie per ha en per koe.

Verschillen in bodemoverschot worden voornamelijk bepaald door bemesting en gewasopbrengst. De $25 \%$ bedrijven met het laagste stikstofbodemoverschot hebben logischerwijs ook een lager fosfaatbodemoverschot. Het aandeel eiwit van eigen land is hoger. Dit kan samenhangen met een hogere gewasopbrengst, maar ook een hoger aandeel grasland of een lager eiwitgehalte in het rantsoen kunnen meespelen. De gemiddelde bedrijfsintensiteit en melkproductie per koe op de $25 \%$ best presterende bedrijven voor stikstofbodemoverschot is niet duidelijk afwijkend van het gemiddelde 
over alle bedrijven. Hierdoor is de broeikasgasemissie per ha en per ton melk in deze groep ook niet duidelijk afwijkend van het gemiddelde. 


\section{$5 \quad$ Conclusies en aanbevelingen}

\subsection{Conclusies}

De gemiddelde resultaten van de melkveebedrijven in Noord-Nederland laten in vergelijking tussen 2013 en 2017 het volgende beeld zien:

- Het stikstofbodemoverschot is met 15,6\% gedaald, van 167 naar $141 \mathrm{~kg} / \mathrm{ha}$.

- Het stikstofbodemoverschot exclusief veenmineralisatie is met 16,7\% gedaald, van 126 naar 105 $\mathrm{kg} / \mathrm{ha}$.

- Het fosfaatbodemoverschot is gedaald van 12 naar $-4 \mathrm{~kg} / \mathrm{ha}$.

- De on-farm broeikasgasemissie per hectare is met 6,7\% gestegen, van 14.873 naar 15.865 kg CO2eq./ha.

- De on-farm broeikasgasemissie per ton melk is met 5,8\% gedaald, van 1166 naar 1098 kg CO2eq./ton melk.

- De ammoniakemissie per hectare is met $10,7 \%$ toegenomen van 59,0 naar $65,3 \mathrm{~kg} / \mathrm{ha}$.

- De ammoniakemissie per GVE is met $14,4 \%$ toegenomen van 27,0 naar 30,9 kg/GVE.

- Het aandeel eiwit van eigen land ligt met 68\% (2016) en 69\% (2017) gemiddeld ruim boven de $65 \%$, overigens nog zonder te werken met buurtcontracten.

\subsection{Aanbevelingen}

Het gemiddelde van de $25 \%$ best scorende bedrijven op een bepaald kengetal geeft niet aan of alle bedrijven in deze groep ook daadwerkelijk een bepaalde streefwaarde halen of niet. De verschillen tussen de bedrijven kunnen heel groot zijn, wat niet zichtbaar is in een gemiddelde. Het $25 \%$ kwartiel kan daarom een betere maat zijn om te kijken waar de kopgroep van $25 \%$ staat qua mineralenprestatie. Een andere optie is om te kijken hoeveel procent van de bedrijven daadwerkelijk een bepaalde streefwaarde haalt.

In deze studie is gekeken naar de ontwikkeling van het gemiddelde van alle bedrijven, de ontwikkeling van de $25 \%$ best presterende bedrijven op elke kengetal van de mineralenprestatie afzonderlijk en hoe $25 \%$ best presterende bedrijven op het kengetal $\mathrm{N}$-bodemoverschot (exclusief veenmineralisatie) scoren op de andere kengetallen. Om een vollediger beeld te krijgen, verdient het aanbeveling om na te gaan in welke mate bedrijven integraal goed scoren op alle kengetallen door te kijken hoeveel bedrijven alle streefwaarden halen en wat de kenmerken van deze bedrijven zijn. Hiervoor dient er wel een bedrijfsspecifieke norm voor sommige kengetallen te worden berekend voor bedrijven met meerdere grondsoorten om de streefwaarden per grondsoort te kunnen vertalen naar een streefwaarde voor elk bedrijf in de dataset.

Wanneer gekeken wordt naar de $25 \%$ best presterende bedrijven op stikstofbodemoverschot is het in verband met jaarvariatie in bodemoverschot beter om uit te gaan van een meer jaarlijks gemiddelde.

Voor een zuivere vergelijking tussen jaren is het belangrijk dat resultaten doorgerekend worden met dezelfde (meest recente) versie van de KringloopWijzer. Hiervoor zal de Centrale Database KringloopWijzer gepast dienen te worden om de resultaten van alle melkveebedrijven over meerdere jaren met de meest recente versie door te kunnen rekenen. 


\section{Literatuur}

CG, 2018. Grondgebondenheid als basis voor een toekomstbestendige melkveehouderij. Commissie Grondgebondheid. 12 april 2018. 61 blz.

Daatselaar, C., H. Prins, en T. de Koeijer. 2015. Duurzaamheid van melkveebedrijven in NoordNederland. Den Haag, Nederland, LEI Wageningen UR. LEI report 2015-087. edepot.wur.nl/349652

Daatselaar, C., 2019. Persoonlijke mededeling. Wageningen Economic Research.

Greenlincs, 2015. Versnellingsagenda melkveehouderij Noord-Nederland. AgroAgenda Noord Nederland. http://www.greenlincs.nl/wp-content/uploads/2015/08/Versnellingsagenda-2015.pdf Hilhorst, Gerjan en Marleen Plomp (2018). Resultaten KringloopWijzer 2013-2017. Vruchtbare Kringloop Achterhoek en Liemers

Schröder. J.J., L.B. Sebek, J. Oenema. J.G. Conijn, en J. de Boer. 2017. Rekenregels van de KringloopWijzer 2016; Achtergronden van BEX, BEA, BEN, BEP en BEC: actualisatie van de 2015versie. Wageningen Research, Rapport WPR-686. 98 blz.

Schröder. J.J., L.B. Sebek, J. Oenema. J.G. Conijn, en J. de Boer. 2018. Rekenregels van de KringloopWijzer 2017; Achtergronden van BEX, BEA, BEN, BEP en BEC: actualisatie van de 2016versie. Wageningen Research, Rapport WPR-790. $106 \mathrm{blz}$.

Wikipedia. 2019. Postcodes in Nederland. https://nl.wikipedia.org/wiki/Postcodes_in_Nederland. Geraadpleegd op 7 januari 2019. 


\section{Bijlage 1 Doelen versnellingsagenda melkveehouderij Noord- Nederland}

Tabel A Duurzaamheidsdoelen Versnellingsagenda melkveehouderij Noord-Nederland (Greenlincs, 2015).

\begin{tabular}{|c|c|}
\hline Thema & Doelen \\
\hline $\begin{array}{l}\text { Bodem, lucht en } \\
\text { waterkwaliteit }\end{array}$ & $\begin{array}{l}\text { - } \quad \text { Fosfaatbodemoverschot } 0 \mathrm{~kg} \text { fosfaat/ha voor fosfaattoestand neutraal. } \\
\text { - Stikstofbodemoverschot: voor klei- en zandregio ca. } 125 \mathrm{~kg} \mathrm{~N} / \mathrm{ha} \text {; voor veenregio ca. } 75 \mathrm{~kg} \\
\mathrm{~N} / \mathrm{ha} \text { hier mineralisatie niet meenemen. } \\
\text { - Ammoniakemissie } 25 \mathrm{~kg} / \mathrm{GVE} \text { op klei en veen, } 20 \mathrm{~kg} / \mathrm{GVE} \text { op zand. }\end{array}$ \\
\hline Biodiversiteit & $\begin{array}{l}\text { - Behoud en ontwikkeling biodiversiteit gerelateerd aan effecten melkveehouderij in Nederland } \\
\text { en elders. Meetbare doelen worden vastgesteld in } 2017 . \\
\text { - Organische stofbalans op bedrijfsniveau positief. } \\
\text { - Aantal melkveehouders dat deelneemt aan agrarisch natuurbeheer is stabiel ten opzichte van } \\
2012 \text {. }\end{array}$ \\
\hline Weidegang & Gelijk aan percentage weidegang in $2012(81,4 \%)$ \\
\hline $\begin{array}{l}\text { Klimaat en energie } \\
\text { (duurzame } \\
\text { zuivelketen) }\end{array}$ & $\begin{array}{l}\text { - } 20 \% \text { reductie van broeikasgassen in } 2020 \text { ten opzichte van } 1990 \text {, inclusief klimaatneutrale } \\
\text { groei. } \\
16 \% \text { duurzame energie in } 2020 \text {. } \\
\text { - } \quad \text { Een energieneutrale zuivelketen in de periode } 2005-2020 \text {. } \\
\text { - } 2 \% \text { energiebesparing per jaar bij veehouders. }\end{array}$ \\
\hline $\begin{array}{l}\text { Diergezondheid en } \\
\text { dierenwelzijn } \\
\text { (duurzame } \\
\text { zuivelketen) }\end{array}$ & $\begin{array}{l}\text { - } \quad \text { Vermindering antibioticaresistentie door bewust antibioticagebruik. } \\
\text { - } \quad \text { Verlengen gemiddelde levensduur koeien met zes maanden ten opzichte van } 2011 .\end{array}$ \\
\hline Werkgelegenheid & $\begin{array}{l}\text { - Bijdragen aan de werkgelegenheid door creëren van toegevoegde waarde in de } \\
\text { melkveehouderij en zuivelketen. }\end{array}$ \\
\hline $\begin{array}{l}\text { Deelname } \\
\text { melkveehouders }\end{array}$ & $\begin{array}{l}\text { - Minimaal } 25 \% \text { van de melkveehouders in Noord-Nederland neemt actief maatregelen om } \\
\text { duurzaamheid te bevorderen (deelname aan projecten, praktijknetwerken vormt daarbij de } \\
\text { maatstaf). }\end{array}$ \\
\hline
\end{tabular}




\section{Bijlage 2 Overzicht mineralenprestaties 2016}

Tabel A Gemiddelde en spreiding van de resultaten in Nederland, Noord-Nederland en Noordelijke provincies over 2016.

\begin{tabular}{|c|c|c|c|c|c|c|c|c|c|c|}
\hline \multirow[t]{2}{*}{ Regio } & \multicolumn{2}{|c|}{ Nederland } & \multicolumn{2}{|c|}{ Noord-Nederland } & \multicolumn{2}{|c|}{ Drenthe } & \multicolumn{2}{|c|}{ Friesland } & \multicolumn{2}{|c|}{ Groningen } \\
\hline & Gemiddeld & SD & Gemiddeld & Spreiding & Gemiddeld & Spreiding & Gemiddeld & Spreiding & Gemiddeld & Spreiding \\
\hline Aantal bedrijven & 11.299 & & 3.250 & & 666 & & 1.947 & & 637 & \\
\hline \multicolumn{11}{|l|}{ Mineralenprestaties } \\
\hline $\mathrm{N}$-bodemoverschot $(\mathrm{kg} / \mathrm{ha})$ & 139 & 80 & 135 & 79 & 122 & 61 & 141 & 87 & 133 & 69 \\
\hline $\mathrm{N}$-bodemoverschot excl. veenmineralisatie $(\mathrm{kg} / \mathrm{ha})$ & 107 & 62 & 101 & 62 & 100 & 52 & 93 & 62 & 124 & 66 \\
\hline P2O5-bodemoverschot $(\mathrm{kg} / \mathrm{ha})$ & -7 & 18 & -7 & 18 & -2 & 16 & -8 & 19 & -7 & 19 \\
\hline NH3-emissie (kg/ha) & 63,1 & 16,7 & 66,1 & 16,2 & 58,0 & 14,8 & 68,8 & 15,5 & 66,2 & 17,0 \\
\hline NH3-emissie (kg/GVE) & 27,3 & 7,0 & 30,0 & 6,7 & 26,7 & 5,7 & 31,2 & 6,5 & 30,2 & 6,8 \\
\hline Aandeel eiwit van eigen land (\%) & 63 & 14 & 68 & 13 & 64 & 12 & 70 & 13 & 68 & 13 \\
\hline \multicolumn{11}{|l|}{ Broeikasgasemissie per hectare } \\
\hline - on-farm (kg CO2-eq./ha) & 15.969 & 3.402 & 15.765 & 3.124 & 14.749 & 3.140 & 16.275 & 3.039 & 15.272 & 3.022 \\
\hline - $\quad$ totaal (kg CO2-eq./ha) & 21.719 & 5.052 & 21.433 & 4.660 & 20.084 & 4.647 & 22.075 & 4.513 & 20.881 & 4.744 \\
\hline - $\quad$ on-farm excl. veenmineralisatie (kg CO2-eq./ha) & 15.798 & 3.300 & 15.581 & 2.996 & 14.630 & 3.088 & 16.023 & 2.864 & 15.224 & 3.013 \\
\hline - $\quad$ totaal excl. veenmineralisatie (kg CO2-eq./ha) & 21.548 & 4.993 & 21.248 & 4.578 & 19.966 & 4.616 & 21.823 & 4.402 & 20.833 & 4.742 \\
\hline \multicolumn{11}{|l|}{ Broeikasgasemissie per ton melk } \\
\hline - $\quad$ on-farm (kg CO2-eq./ton melk) & 1.063 & 215 & 1.106 & 195 & 1.046 & 176 & 1.127 & 198 & 1.105 & 194 \\
\hline - $\quad$ totaal (kg CO2-eq./ton melk) & 1.433 & 242 & 1.492 & 221 & 1.413 & 198 & 1.517 & 221 & 1.497 & 223 \\
\hline - $\quad$ on-farm excl. veenmineralisatie (kg CO2-eq./ton melk) & 1.051 & 198 & 1.093 & 181 & 1.037 & 167 & 1.109 & 179 & 1.101 & 189 \\
\hline - $\quad$ totaal excl. veenmineralisatie (kg CO2-eq./ton melk) & 1.420 & 227 & 1.478 & 208 & 1.404 & 191 & 1.499 & 204 & 1.493 & 218 \\
\hline \multicolumn{11}{|l|}{ Bedrijfsstructuur } \\
\hline Intensiteit (kg melk/ha) & 15.628 & 4.578 & 14.670 & 3.749 & 14.571 & 4.090 & 14.819 & 3.537 & 14.317 & 3.973 \\
\hline Oppervlakte (ha) & 53,6 & 30,2 & 66,7 & 35,8 & 65,7 & 37,3 & 65,8 & 34,5 & 70,2 & 37,7 \\
\hline Aandeel maisland (\%) & $12 \%$ & $10 \%$ & $9 \%$ & $9 \%$ & $16 \%$ & $7 \%$ & $7 \%$ & $8 \%$ & $7 \%$ & $9 \%$ \\
\hline Aandeel klei (\%) & 36 & 43 & 42 & 46 & 2 & 8 & 47 & 47 & 70 & 42 \\
\hline Aandeel veen $(\%)$ & 14 & 30 & 15 & 29 & 10 & 19 & 20 & 34 & 4 & 13 \\
\hline Aandeel zand (\%) & 51 & 46 & 43 & 45 & 88 & 21 & 33 & 42 & 26 & 40 \\
\hline Melkproductie bedrijf ( $\mathrm{kg}$ melk per bedrijf) & 833.901 & 524.005 & 988.095 & 614.549 & 955.178 & 594.120 & 989.297 & 603.987 & 1.018 .838 & 663.885 \\
\hline Melkproductie per koe (kg melk/koe) & 8.145 & 1.196 & 8.098 & 1.099 & 8.180 & 1.088 & 8.113 & 1.085 & 7.966 & 1.141 \\
\hline Aantal koeien & 100,3 & 57,9 & 119,9 & 68,4 & 115,0 & 66,3 & 119,9 & 67,1 & 125,1 & 73,9 \\
\hline Aantal GVE per koe (GVE/koe) & 1,25 & 0,18 & 1,24 & 0,13 & 1,25 & 0,13 & 1,23 & 0,11 & 1,25 & 0,18 \\
\hline Uren weidegang & 1.023 & 963 & 1.030 & 966 & 836 & 809 & 1.040 & 968 & 1.201 & 1.070 \\
\hline
\end{tabular}


Tabel B Gemiddelde en spreiding van de resultaten per grondsoort in Nederland en Noord-Nederland over 2016.

\begin{tabular}{|c|c|c|c|c|c|c|c|c|}
\hline \multirow{2}{*}{$\begin{array}{l}\text { Regio } \\
\text { Grondsoort }\end{array}$} & \multicolumn{4}{|c|}{ Nederland } & \multicolumn{4}{|c|}{ Noord-Nederland } \\
\hline & Klei & Veen & Zand & Overig & Klei & Veen & Zand & Overig \\
\hline Aantal bedrijven & 2.493 & 590 & 4.089 & 4.127 & 1.020 & 169 & 829 & 1.232 \\
\hline \multicolumn{9}{|l|}{ Mineralenprestaties } \\
\hline N-bodemoverschot $(\mathrm{kg} / \mathrm{ha})$ & 132 & 296 & 101 & 159 & 118 & 292 & 100 & 152 \\
\hline $\mathrm{N}$-bodemoverschot excl. veenmineralisatie $(\mathrm{kg} / \mathrm{ha})$ & 132 & 61 & 101 & 104 & 118 & 57 & 100 & 92 \\
\hline P2O5-bodemoverschot $(\mathrm{kg} / \mathrm{ha})$ & -9 & -5 & -8 & -6 & -12 & -9 & -2 & -6 \\
\hline $\mathrm{NH} 3$-emissie $(\mathrm{kg} / \mathrm{ha})$ & 67,4 & 68,6 & 59,0 & 63,8 & 71,3 & 71,5 & 59,1 & 65,7 \\
\hline NH3-emissie (kg/GVE) & 30,0 & 31,1 & 24,2 & 28,2 & 31,8 & 32,2 & 27,5 & 30,0 \\
\hline \multicolumn{9}{|l|}{ Broeikasgasemissie per hectare } \\
\hline - $\quad$ on-farm (kg CO2-eq./ha) & 15.339 & 19.226 & 15.707 & 16.143 & 15.842 & 19.690 & 14.424 & 16.066 \\
\hline - $\quad$ totaal (kg CO2-eq./ha) & 21.035 & 24.551 & 21.613 & 21.833 & 21.787 & 25.370 & 19.763 & 21.722 \\
\hline - $\quad$ on-farm excl. veenmineralisatie ( $\mathrm{kg} \mathrm{CO2-eq./ha)}$ & 15.339 & 17.981 & 15.707 & 15.852 & 15.842 & 18.445 & 14.424 & 15.751 \\
\hline - $\quad$ totaal excl. veenmineralisatie (kg CO2-eq./ha) & 21.035 & 23.306 & 21.613 & 21.542 & 21.787 & 24.125 & 19.763 & 21.407 \\
\hline \multicolumn{9}{|l|}{ Broeikasgasemissie per ton melk } \\
\hline - on-farm (kg CO2-eq./ton melk) & 1.056 & 1.407 & 977 & 1.104 & 1.085 & 1.368 & 1.030 & 1.139 \\
\hline - $\quad$ totaal (kg CO2-eq./ton melk) & 1.438 & 1.781 & 1.333 & 1.479 & 1.481 & 1.751 & 1.401 & 1.526 \\
\hline - $\quad$ totaal excl. veenmineralisatie (kg CO2-eq./ton melk) & 1.438 & 1.685 & 1.333 & 1.457 & 1.481 & 1.662 & 1.401 & 1.502 \\
\hline \multicolumn{9}{|l|}{ Bedrijfsstructuur } \\
\hline Intensiteit ( $\mathrm{kg} \mathrm{melk/ha)}$ & 14.996 & 14.196 & 16.636 & 15.216 & 14.953 & 14.796 & 14.426 & 14.582 \\
\hline Oppervlakte (ha) & 57,5 & 47,5 & 45,6 & 60,1 & 64,4 & 59,8 & 61,2 & 73,1 \\
\hline Aandeel maisland (\%) & $8 \%$ & $3 \%$ & $16 \%$ & $12 \%$ & $3 \%$ & $5 \%$ & $14 \%$ & $10 \%$ \\
\hline Aandeel klei (\%) & 100 & 0 & 0 & 37 & 100 & 0 & 0 & 29 \\
\hline Aandeel veen $(\%)$ & 0 & 100 & 0 & 23 & 0 & 100 & 0 & 25 \\
\hline Aandeel zand (\%) & 0 & 0 & 100 & 39 & 0 & 0 & 100 & 46 \\
\hline Melkproductie bedrijf ( $\mathrm{kg}$ melk per bedrijf) & 872.214 & 671.261 & 754.185 & 912.990 & 979.284 & 898.915 & 891.236 & 1.072 .799 \\
\hline Melkproductie per koe (kg melk/koe) & 8.142 & 7.668 & 8.218 & 8.142 & 8.088 & 7.970 & 8.175 & 8.072 \\
\hline Aantal koeien & 104,8 & 85,6 & 90,0 & 110,0 & 118,8 & 110,3 & 107,0 & 130,9 \\
\hline Aantal GVE per koe (GVE/koe) & 1,25 & 1,22 & 1,25 & 1,25 & 1,23 & 1,22 & 1,25 & 1,24 \\
\hline Uren weidegang & 1.225 & 1.721 & 791 & 1.032 & 1.173 & 1.120 & 933 & 965 \\
\hline
\end{tabular}




\section{Bijlage 3 Overzicht mineralenprestaties 2017}

Tabel A

Gemiddelde en spreiding van de resultaten in Nederland, Noord-Nederland en Noordelijke provincies over 2017.

\begin{tabular}{|c|c|c|c|c|c|c|c|c|c|c|}
\hline \multirow[t]{2}{*}{ Regio } & \multicolumn{4}{|c|}{$\begin{array}{l}\text { Noord- } \\
\text { Nederland }\end{array}$} & \multicolumn{3}{|c|}{ Friesland } & \multicolumn{3}{|c|}{ Groningen } \\
\hline & Gemiddeld & Spreiding & Gemiddeld & Spreiding & Gemiddeld & Spreiding & Gemiddeld & Spreiding & Gemiddeld & Spreiding \\
\hline Aantal bedrijven & 11.204 & & 3.071 & & 656 & & 1.856 & & 559 & \\
\hline \multicolumn{11}{|l|}{ Mineralenprestaties } \\
\hline $\mathrm{N}$-bodemoverschot $(\mathrm{kg} / \mathrm{ha})$ & 129 & 82 & 141 & 83 & 124 & 65 & 150 & 90 & 130 & 72 \\
\hline $\mathrm{N}$-bodemoverschot excl. veenmineralisatie $(\mathrm{kg} / \mathrm{ha})$ & 97 & 63 & 105 & 60 & 103 & 55 & 102 & 59 & 116 & 65 \\
\hline P2O5-bodemoverschot $(\mathrm{kg} / \mathrm{ha})$ & -7 & 20 & -4 & 19 & 0 & 18 & -3 & 19 & -10 & 19 \\
\hline NH3-emissie (kg/ha) & 64,1 & 16,5 & 65,3 & 14,3 & 58,4 & 14 & 67,5 & 13 & 66,4 & 16 \\
\hline NH3-emissie (kg/GVE) & 28,0 & 6,2 & 30,9 & 5,7 & 27,5 & 5 & 32,0 & 5 & 31,4 & 6 \\
\hline Aandeel eiwit van eigen land (\%) & 66 & 16 & 69 & 15 & 63 & 13 & 70 & 15 & 70 & 15 \\
\hline \multicolumn{11}{|l|}{ Broeikasgasemissie per hectare } \\
\hline - on-farm (kg CO2-eq./ha) & 16.801 & 4.807 & 15.865 & 3.288 & 15.228 & 3.539 & 16.197 & 3.064 & 15.507 & 3.544 \\
\hline - $\quad$ totaal (kg CO2-eq./ha) & 23.690 & 7.978 & 22.123 & 5.166 & 21.238 & 5.591 & 22.553 & 4.797 & 21.735 & 5.643 \\
\hline - $\quad$ on-farm excl. veenmineralisatie ( $\mathrm{kg} \mathrm{CO2-eq./ha)}$ & 16.633 & 4.763 & 15.674 & 3.174 & 15.119 & 3.492 & 15.942 & 2.910 & 15.434 & 3.504 \\
\hline - $\quad$ totaal excl. veenmineralisatie (kg CO2-eq./ha) & 23.522 & 7.969 & 21.932 & 5.096 & 21.129 & 5.560 & 22.298 & 4.708 & 21.662 & 5.615 \\
\hline \multicolumn{11}{|l|}{ Broeikasgasemissie per ton melk } \\
\hline - $\quad$ on-farm (kg CO2-eq./ton melk) & 1.058 & 223 & 1.098 & 221 & 1.035 & 185 & 1.125 & 235 & 1.083 & 196 \\
\hline - $\quad$ totaal (kg CO2-eq./ton melk) & 1.467 & 245 & 1.515 & 245 & 1.427 & 209 & 1.551 & 255 & 1.500 & 219 \\
\hline - $\quad$ on-farm excl. veenmineralisatie ( $\mathrm{kg} \mathrm{CO2-eq./ton} \mathrm{melk)}$ & 1.045 & 205 & 1.084 & 204 & 1.027 & 176 & 1.106 & 214 & 1.077 & 187 \\
\hline - $\quad$ totaal excl. veenmineralisatie (kg CO2-eq./ton melk) & 1.455 & 229 & 1.501 & 228 & 1.419 & 201 & 1.532 & 235 & 1.494 & 211 \\
\hline \multicolumn{11}{|l|}{ Bedrijfsstructuur } \\
\hline Intensiteit (kg melk/ha) & 16.728 & 6.857 & 14.973 & 4.234 & 15.312 & 4.884 & 14.880 & 3.844 & 14.886 & 4.609 \\
\hline Oppervlakte (ha) & 53,4 & 31,6 & 66,8 & 37,6 & 66,0 & 37,5 & 66,1 & 37,3 & 70,1 & 38,6 \\
\hline Aandeel maisland (\%) & $12 \%$ & $10 \%$ & $9 \%$ & $9 \%$ & $16 \%$ & $7 \%$ & $7 \%$ & $8 \%$ & $7 \%$ & $9 \%$ \\
\hline Aandeel klei (\%) & 35 & 43 & 41 & 46 & 3 & 9 & 46 & 47 & 71 & 41 \\
\hline Aandeel veen (\%) & 13 & 29 & 15 & 30 & 9 & 19 & 20 & 35 & 6 & 17 \\
\hline Aandeel zand (\%) & 52 & 46 & 43 & 45 & 89 & 21 & 33 & 42 & 23 & 38 \\
\hline Melkproductie bedrijf ( $\mathrm{kg}$ melk per bedrijf) & 877.875 & 623.595 & 1.014 .299 & 704.323 & 1.007 .538 & 689.353 & 1.001 .135 & 687.641 & 1.065 .943 & 770.947 \\
\hline Melkproductie per koe (kg melk/koe) & 8.510 & 1.273 & 8.441 & 1.172 & 8.610 & 1.153 & 8.396 & 1.142 & 8.392 & 1.271 \\
\hline Aantal koeien & 100,6 & 65,1 & 117,5 & 74,3 & 114,4 & 71,3 & 116,8 & 73,1 & 123,6 & 81,2 \\
\hline Aantal GVE per koe (GVE/koe) & 1,23 & 0,19 & 1,22 & 0,15 & 1,23 & 0,10 & 1,22 & 0,17 & 1,23 & 0,13 \\
\hline Uren weidegang & 1.037 & 968 & 1.069 & 985 & 859 & 856 & 1.076 & 974 & 1.291 & 1.105 \\
\hline
\end{tabular}


Tabel B Gemiddelde en spreiding van de resultaten per grondsoort in Nederland en Noord-Nederland over 2017

\begin{tabular}{|c|c|c|c|c|c|c|c|c|}
\hline \multirow{2}{*}{$\begin{array}{l}\text { Regio } \\
\text { Grondsoort }\end{array}$} & \multicolumn{4}{|c|}{ Nederland } & \multicolumn{4}{|c|}{ Noord-Nederland } \\
\hline & Klei & Veen & Zand & Overig & Klei & Veen & Zand & Overig \\
\hline Aantal bedrijven & 2.371 & 558 & 4.164 & 4.111 & 938 & 167 & 794 & 1.172 \\
\hline \multicolumn{9}{|l|}{ Mineralenprestaties } \\
\hline $\mathrm{N}$-bodemoverschot (kg/ha) & 124 & 285 & 89 & 151 & 117 & 308 & 105 & 160 \\
\hline $\mathrm{N}$-bodemoverschot excl. veenmineralisatie $(\mathrm{kg} / \mathrm{ha})$ & 124 & 50 & 89 & 97 & 117 & 73 & 105 & 99 \\
\hline P2O5-bodemoverschot $(\mathrm{kg} / \mathrm{ha})$ & -8 & -5 & -9 & -5 & -10 & -2 & 1 & -3 \\
\hline NH3-emissie $(\mathrm{kg} / \mathrm{ha})$ & 67,7 & 68,0 & 61,4 & 64,2 & 70,9 & 68,8 & 58,3 & 65,2 \\
\hline NH3-emissie (kg/GVE) & 30,9 & 32,0 & 24,7 & 29,0 & 33,2 & 33,0 & 28,1 & 30,7 \\
\hline \multicolumn{9}{|l|}{ Broeikasgasemissie per hectare } \\
\hline - $\quad$ on-farm (kg CO2-eq./ha) & 15.760 & 19.279 & 17.144 & 16.716 & 15.675 & 19.196 & 14.627 & 16.380 \\
\hline - $\quad$ totaal (kg CO2-eq./ha) & 22.268 & 25.159 & 24.656 & 23.334 & 22.101 & 25.394 & 20.550 & 22.741 \\
\hline - $\quad$ on-farm excl. veenmineralisatie ( $\mathrm{kg} \mathrm{CO2-eq./ha)}$ & 15.760 & 18.034 & 17.144 & 16.427 & 15.675 & 17.950 & 14.627 & 16.057 \\
\hline - $\quad$ totaal excl. veenmineralisatie (kg CO2-eq./ha) & 22.268 & 23.913 & 24.656 & 23.045 & 22.101 & 24.149 & 20.550 & 22.419 \\
\hline \multicolumn{9}{|l|}{ Broeikasgasemissie per ton melk } \\
\hline - on-farm (kg CO2-eq./ton melk) & 1.053 & 1.405 & 974 & 1.099 & 1.072 & 1.374 & 1.023 & 1.131 \\
\hline - $\quad$ totaal (kg CO2-eq./ton melk) & 1.471 & 1.813 & 1.375 & 1.511 & 1.497 & 1.806 & 1.424 & 1.550 \\
\hline - $\quad$ totaal excl. veenmineralisatie (kg CO2-eq./ton melk) & 1.471 & 1.716 & 1.375 & 1.490 & 1.497 & 1.713 & 1.424 & 1.526 \\
\hline \multicolumn{9}{|l|}{ Bedrijfsstructuur } \\
\hline Intensiteit ( $\mathrm{kg}$ melk/ha) & 15.582 & 14.363 & 18.429 & 15.987 & 15.044 & 14.424 & 14.772 & 15.130 \\
\hline Oppervlakte (ha) & 57,9 & 48,3 & 45,0 & 60,0 & 64,3 & 60,3 & 60,8 & 73,8 \\
\hline Aandeel maisland (\%) & $8 \%$ & $3 \%$ & $16 \%$ & $12 \%$ & $3 \%$ & $5 \%$ & $14 \%$ & $10 \%$ \\
\hline Aandeel klei (\%) & 100 & 0 & 0 & 37 & 100 & 0 & 0 & 28 \\
\hline Aandeel veen $(\%)$ & 0 & 100 & 0 & 23 & 0 & 100 & 0 & 26 \\
\hline Aandeel zand (\%) & 0 & 0 & 100 & 40 & 0 & 0 & 100 & 46 \\
\hline Melkproductie bedrijf ( $\mathrm{kg}$ melk per bedrijf) & 901.716 & 687.870 & 804.280 & 964.459 & 982.402 & 882.373 & 897.703 & 1.137 .617 \\
\hline Melkproductie per koe (kg melk/koe) & 8.478 & 7.920 & 8.621 & 8.498 & 8.368 & 8.197 & 8.515 & 8.483 \\
\hline Aantal koeien & 103,8 & 84,5 & 91,0 & 110,6 & 114,7 & 105,5 & 103,3 & 131,1 \\
\hline Aantal GVE per koe (GVE/koe) & 1,24 & 1,21 & 1,23 & 1,23 & 1,22 & 1,21 & 1,23 & 1,23 \\
\hline Uren weidegang & 1.244 & 1.689 & 804 & 1.066 & 1.215 & 1.022 & 1.029 & 985 \\
\hline
\end{tabular}




\section{Bijlage 4 Resultaten Nederland en Noord-Nederland 2013, 2016 en 2017}

Tabel A Gemiddelde voor Nederland en Noord-Nederland

\begin{tabular}{|c|c|c|c|c|c|c|}
\hline \multirow{2}{*}{$\begin{array}{l}\text { Regio } \\
\text { Bron }\end{array}$} & \multicolumn{3}{|c|}{ Nederland } & \multicolumn{3}{|c|}{ Noord-Nederland } \\
\hline & BIN & KLW & KLW & BIN & KLW & KLW \\
\hline Jaar & 2013 & 2016 & 2017 & 2013 & 2016 & 2017 \\
\hline Aantal bedrijven & & 11.299 & 11.204 & & 3.252 & 3.071 \\
\hline \multicolumn{7}{|l|}{ Mineralenprestaties } \\
\hline N-bodemoverschot $(\mathrm{kg} / \mathrm{ha})$ & 166 & 139 & 129 & 167 & 135 & 141 \\
\hline $\mathrm{N}$-bodemoverschot excl. veenmineralisatie $(\mathrm{kg} / \mathrm{ha})$ & 132 & 107 & 97 & 126 & 101 & 105 \\
\hline P2O5-bodemoverschot (kg/ha) & 16 & -7 & -7 & 12 & -7 & -4 \\
\hline NH3-emissie $(\mathrm{kg} / \mathrm{ha})$ & 56 & 63,1 & 64,1 & 59,0 & 66,1 & 65,3 \\
\hline NH3-emissie (kg/GVE) & 24 & 27,3 & 28,0 & 27,0 & 30,0 & 30,9 \\
\hline Aandeel eiwit van eigen land (\%) & - & 63 & 66 & - & 68 & 69 \\
\hline \multicolumn{7}{|l|}{ Broeikasgasemissie per hectare } \\
\hline - on-farm (kg CO2-eq./ha) & $15.622^{1)}$ & 15.969 & 16.801 & $14.873^{1)}$ & 15.767 & 15.865 \\
\hline - $\quad$ totaal $(\mathrm{kg} \mathrm{CO}-$ eq./ha) & - & 21.719 & 23.690 & - & 21.435 & 22.123 \\
\hline - $\quad$ on-farm excl. veenmineralisatie (kg CO2-eq./ha) & - & 15.798 & 16.633 & - & 15.583 & 15.674 \\
\hline - $\quad$ totaal excl. veenmineralisatie (kg CO2-eq./ha) & - & 21.548 & 23.522 & - & 21.250 & 21.932 \\
\hline \multicolumn{7}{|l|}{ Broeikasgasemissie per ton melk } \\
\hline - $\quad$ on-farm (kg CO2-eq./ton melk) & $1.060^{1)}$ & 1.063 & 1.058 & $1.166^{1)}$ & 1.106 & 1.098 \\
\hline totaal (kg CO2-eq./ton melk) & - & 1.433 & 1.467 & - & 1.492 & 1.515 \\
\hline on-farm excl. veenmineralisatie (kg CO2-eq./ton melk) & - & 1.051 & 1.045 & - & 1.093 & 1.084 \\
\hline totaal excl. veenmineralisatie (kg CO2-eq./ton melk) & - & 1.420 & 1.455 & - & 1.478 & 1.501 \\
\hline \multicolumn{7}{|l|}{ Bedrijfsstructuur } \\
\hline Intensiteit (kg melk/ha) & 14.600 & 15.628 & 16.728 & 13.500 & 14.674 & 14.973 \\
\hline Oppervlakte (ha) & 49 & 53,6 & 53,4 & 59,0 & 66,6 & 66,8 \\
\hline Aandeel maisland (\%) & $18 \%$ & $12 \%$ & $12 \%$ & $11 \%$ & $9 \%$ & $9 \%$ \\
\hline Aandeel klei (\%) & 30 & 36 & 35 & 40 & 42 & 41 \\
\hline Aandeel veen (\%) & 18 & 14 & 13 & 18 & 15 & 15 \\
\hline Aandeel zand (\%) & 52 & 51 & 52 & 42 & 43 & 43 \\
\hline Melkproductie bedrijf (kg melk per bedrijf) & 714.000 & 833.901 & 877.875 & 791.000 & 987.966 & 1.014 .299 \\
\hline Melkproductie per koe (kg melk/koe) & 7.950 & 8.145 & 8.510 & 7.800 & 8.098 & 8.441 \\
\hline Aantal koeien & - & 100 & 101 & - & 120 & 118 \\
\hline Aantal GVE per koe (GVE/koe) & 1,25 & 1,25 & 1,23 & 1,27 & 1,24 & 1,22 \\
\hline Uren weidegang & - & 1.023 & 1.037 & - & 1.029 & 1.069 \\
\hline
\end{tabular}

1) Betreft gecorrigeerde/berekende waarde n.a.v. wijziging in rekensystematiek vanaf 2016. 


\section{Bijlage 5 Resultaten per provincie over 2016 en 2017}

Tabel A Gemiddelde per provincie over 2016 en 2017

\begin{tabular}{|c|c|c|c|c|c|c|}
\hline \multirow{2}{*}{$\begin{array}{l}\text { Regio } \\
\text { Bron } \\
\end{array}$} & \multicolumn{2}{|c|}{ Drenthe } & \multicolumn{2}{|c|}{ Friesland } & \multicolumn{2}{|c|}{ Groningen } \\
\hline & KLW & KLW & KLW & KLW & KLW & KLW \\
\hline Jaar & 2016 & 2017 & 2016 & 2017 & 2016 & 2017 \\
\hline Aantal bedrijven & 666 & 656 & 1.947 & 1.856 & 637 & 559 \\
\hline \multicolumn{7}{|l|}{ Mineralenprestaties } \\
\hline N-bodemoverschot (kg/ha) & 122 & 124 & 141 & 150 & 133 & 130 \\
\hline $\mathrm{N}$-bodemoverschot excl. veenmineralisatie (kg/ha) & 100 & 103 & 93 & 102 & 124 & 116 \\
\hline P2O5-bodemoverschot (kg/ha) & -2 & 0 & -8 & -3 & -7 & -10 \\
\hline NH3-emissie (kg/ha) & 58,0 & 58,4 & 68,8 & 67,5 & 66,2 & 66,4 \\
\hline NH3-emissie (kg/GVE) & 26,7 & 27,5 & 31,2 & 32,0 & 30,2 & 31,4 \\
\hline Aandeel eiwit van eigen land (\%) & 64 & 63 & 70 & 70 & 68 & 70 \\
\hline \multicolumn{7}{|l|}{ Broeikasgasemissie per hectare } \\
\hline - on-farm (kg CO2-eq./ha) & 14.749 & 15.228 & 16.275 & 16.197 & 15.272 & 15.507 \\
\hline - $\quad$ totaal $(\mathrm{kg} \mathrm{CO}-$ eq. $/ \mathrm{ha})$ & 20.084 & 21.238 & 22.075 & 22.553 & 20.881 & 21.735 \\
\hline - $\quad$ on-farm excl. veenmineralisatie (kg CO2-eq./ha) & 14.630 & 15.119 & 16.023 & 15.942 & 15.224 & 15.434 \\
\hline - $\quad$ totaal excl. veenmineralisatie (kg CO2-eq./ha) & 19.966 & 21.129 & 21.823 & 22.298 & 20.833 & 21.662 \\
\hline \multicolumn{7}{|l|}{ Broeikasgasemissie per ton melk } \\
\hline - $\quad$ on-farm (kg CO2-eq./ton melk) & 1.046 & 1.035 & 1.127 & 1.125 & 1.105 & 1.083 \\
\hline - $\quad$ totaal (kg CO2-eq./ton melk) & 1.413 & 1.427 & 1.517 & 1.551 & 1.497 & 1.500 \\
\hline - $\quad$ on-farm excl. veenmineralisatie (kg CO2-eq./ton melk) & 1.037 & 1.027 & 1.109 & 1.106 & 1.101 & 1.077 \\
\hline - $\quad$ totaal excl. veenmineralisatie (kg CO2-eq./ton melk) & 1.404 & 1.419 & 1.499 & 1.532 & 1.493 & 1.494 \\
\hline \multicolumn{7}{|l|}{ Bedrijfsstructuur } \\
\hline Intensiteit (kg melk/ha) & 14.571 & 15.312 & 14.819 & 14.880 & 14.317 & 14.886 \\
\hline Oppervlakte (ha) & 65,7 & 66,0 & 65,8 & 66,1 & 70,2 & 70,1 \\
\hline Aandeel maisland (\%) & $16 \%$ & $16 \%$ & $7 \%$ & $7 \%$ & $7 \%$ & $7 \%$ \\
\hline Aandeel klei (\%) & 2 & 3 & 47 & 46 & 70 & 71 \\
\hline Aandeel veen (\%) & 10 & 9 & 20 & 20 & 4 & 6 \\
\hline Aandeel zand (\%) & 88 & 89 & 33 & 33 & 26 & 23 \\
\hline Melkproductie bedrijf (kg melk per bedrijf) & 955.178 & 1.007 .538 & 989.297 & 1.001 .135 & 1.018 .838 & 1.065 .943 \\
\hline Melkproductie per koe (kg melk/koe) & 8.180 & 8.610 & 8.113 & 8.396 & 7.966 & 8.392 \\
\hline Aantal koeien & 115 & 114 & 120 & 117 & 125 & 124 \\
\hline Aantal GVE per koe (GVE/koe) & 1,25 & 1,23 & 1,23 & 1,22 & 1,25 & 1,23 \\
\hline Uren weidegang & 836 & 859 & 1.040 & 1.076 & 1.201 & 1.291 \\
\hline
\end{tabular}




\section{Bijlage 6 Resultaten per grondsoort over 2016 en 2017}

Tabel A Gemiddelde per grondsoort voor Nederland over 2016 en 2017

\begin{tabular}{|c|c|c|c|c|c|c|c|c|}
\hline \multirow{2}{*}{$\begin{array}{l}\text { Grondsoort } \\
\text { Jaar }\end{array}$} & \multicolumn{2}{|c|}{ Klei } & \multicolumn{2}{|c|}{ Veen } & \multicolumn{2}{|c|}{ Zand } & \multicolumn{2}{|c|}{ Overig } \\
\hline & 2016 & 2017 & 2016 & 2017 & 2016 & 2017 & 2016 & 2017 \\
\hline Aantal bedrijven & 2.493 & 2.371 & 590 & 558 & 4.089 & 4.164 & 4.127 & 4.111 \\
\hline
\end{tabular}

\section{Mineralenprestaties}

$\mathrm{N}$-bodemoverschot $(\mathrm{kg} / \mathrm{ha})$
$\mathrm{N}$-bodemoverschot excl. veenmineralisatie $(\mathrm{kg} / \mathrm{ha})$

P2O5-bodemoverschot $(\mathrm{kg} / \mathrm{ha})$

$\mathrm{NH} 3$-emissie $(\mathrm{kg} / \mathrm{ha})$

NH3-emissie (kg/GVE)

Aandeel eiwit van eigen land (\%)

\begin{tabular}{cccccccc}
132 & 124 & 296 & 285 & 101 & 89 & 159 & 151 \\
\hline 132 & 124 & 61 & 50 & 101 & 89 & 104 & 97 \\
-9 & -8 & -5 & -5 & -8 & -9 & -6 & -5 \\
67,4 & 67,7 & 68,6 & 68,0 & 59,0 & 61,4 & 63,8 & 64,2 \\
\hline 30,0 & 30,9 & 31,1 & 32,0 & 24,2 & 24,7 & 28,2 & 29,0 \\
\hline 66 & 69 & 70 & 75 & 59 & 61 & 64 & 67 \\
\hline
\end{tabular}

Broeikasgasemissie per hectare

- on-farm (kg CO2-eq./ha)

totaal (kg CO2-eq./ha)

$15.339 \quad 15.760$

on-farm excl. veenmineralisatie ( $\mathrm{kg} \mathrm{CO2-eq./ha)}$

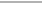

59

61

64

67

Broeikasgasemissie per ton melk

- $\quad$ on-farm (kg CO2-eq./ton melk)

\begin{tabular}{cc}
\hline- & totaal (kg CO2-eq./ton melk) \\
\hline- & on-farm excl. veenmineralisatie (kg CO2-eq./ton melk)
\end{tabular}

totaal excl. veenmineralisatie ( $\mathrm{kg} \mathrm{CO2-eq./ton} \mathrm{melk)}$

$15.339 \quad 15.760$

$19.226 \quad 19.279$

$\begin{array}{llll}15.707 & 17.144 & 16.143 & 16.716\end{array}$

\begin{tabular}{lllllll}
22.268 & 24.551 & 25.159 & 21.613 & 24.656 & 21.833 & 23.334 \\
15.760 & 17.981 & 18.034 & 15.707 & 17.144 & 15.852 & 16.427 \\
\hline
\end{tabular}

\section{Bedrijfsstructuur}

Intensiteit ( $\mathrm{kg} \mathrm{melk/ha)}$

22.268

$23.306 \quad 23.913$

$21.613 \quad 24.656$

$\begin{array}{lllll}18.034 & 15.707 & 17.144 & 15.852 & 16.427 \\ 23.913 & 21.613 & 24.656 & 21.542 & 23.045\end{array}$

Oppervlakte (ha)

Aandeel maisland (\%)

Aandeel klei (\%)

Aandeel veen $(\%)$

Aandeel zand (\%)

Melkproductie bedrijf (kg melk per bedrijf)

$(2.035$

Melkproductie per koe (kg melk/koe)

$1.056 \quad 1.053$

\begin{tabular}{ccccccc}
.053 & 1.407 & 1.405 & 977 & 974 & 1.104 & 1.099 \\
\hline 471 & 1.781 & 1.813 & 1.333 & 1.375 & 1.479 & 1.511
\end{tabular}

$\begin{array}{llllcccr}1.438 & 1.471 & 1.781 & 1.813 & 1.333 & 1.375 & 1.479 & 1.511 \\ 1.056 & 1.053 & 1.311 & 1.309 & 977 & 974 & 1.083 & 1.078 \\ 1.438 & 1.471 & 1.685 & 1.716 & 1.333 & 1.375 & 1.457 & 1.490\end{array}$

Aantal koeien

Aantal GVE per koe (GVE/koe)

Uren weidegang

1.438
1.056
1.438

$1.053 \quad 1.31$

1.309

$\begin{array}{ll}1.083 & 1.078 \\ 1.457 & 1.490\end{array}$

14.996

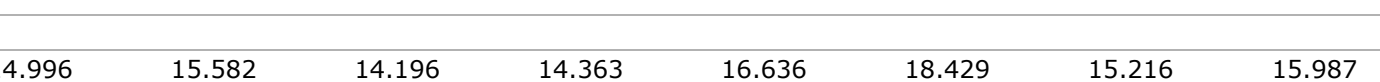

\begin{tabular}{cccccccc}
14.996 & 15.582 & 14.196 & 14.363 & 16.636 & 18.429 & 15.216 & 15.987 \\
\hline 57 & 58 & 47 & 48 & 46 & 45 & 60 & 60 \\
$8 \%$ & $8 \%$ & $3 \%$ & $3 \%$ & $16 \%$ & $16 \%$ & $12 \%$ & $12 \%$ \\
100 & 100 & 0 & 0 & 0 & 0 & 37 & 37 \\
0 & 0 & 100 & 100 & 0 & 0 & 23 & 23 \\
0 & 0 & 0 & 0 & 100 & 100 & 39 & 40 \\
872.214 & 901.716 & 671.261 & 687.870 & 754.185 & 804.280 & 912.990 & 964.459 \\
\hline 8.142 & 8.478 & 7.668 & 7.920 & 8.218 & 8.621 & 8.142 & 8.498 \\
105 & 104 & 86 & 84 & 90 & 91 & 110 & 111 \\
1,25 & 1,24 & 1,22 & 1,21 & 1,25 & 1,23 & 1,25 & 1,23 \\
1.225 & 1.244 & 1.721 & 1.689 & 791 & 804 & 1.032 & 1.066 \\
\hline
\end{tabular}


Tabel B Gemiddelde per grondsoort voor Noord-Nederland over 2016 en 2017

\begin{tabular}{|c|c|c|c|c|c|c|c|c|}
\hline \multirow{2}{*}{$\begin{array}{l}\text { Grondsoort } \\
\text { Jaar }\end{array}$} & \multicolumn{2}{|c|}{ Klei } & \multicolumn{2}{|c|}{ Veen } & \multicolumn{2}{|c|}{ Zand } & \multicolumn{2}{|c|}{ Overig } \\
\hline & 2016 & 2017 & 2016 & 2017 & 2016 & 2017 & 2016 & 2017 \\
\hline Aantal bedrijven & 1.020 & 938 & 169 & 167 & 830 & 794 & 1.233 & 1.172 \\
\hline \multicolumn{9}{|l|}{ Mineralenprestaties } \\
\hline $\mathrm{N}$-bodemoverschot $(\mathrm{kg} / \mathrm{ha})$ & 118 & 117 & 292 & 308 & 100 & 105 & 152 & 160 \\
\hline $\mathrm{N}$-bodemoverschot excl. veenmineralisatie $(\mathrm{kg} / \mathrm{ha})$ & 118 & 117 & 57 & 73 & 100 & 105 & 92 & 99 \\
\hline P2O5-bodemoverschot $(\mathrm{kg} / \mathrm{ha})$ & -12 & -10 & -9 & -2 & -2 & 1 & -6 & -3 \\
\hline NH3-emissie (kg/ha) & 71,3 & 70,9 & 71,5 & 68,8 & 59,2 & 58,3 & 65,7 & 65,2 \\
\hline NH3-emissie (kg/GVE) & 31,8 & 33,2 & 32,2 & 33,0 & 27,5 & 28,1 & 30,0 & 30,7 \\
\hline \multicolumn{9}{|l|}{ Broeikasgasemissie per hectare } \\
\hline - $\quad$ on-farm (kg CO2-eq./ha) & 15.842 & 15.675 & 19.690 & 19.196 & 14.430 & 14.627 & 16.067 & 16.380 \\
\hline - $\quad$ totaal (kg CO2-eq./ha) & 21.787 & 22.101 & 25.370 & 25.394 & 19.772 & 20.550 & 21.723 & 22.741 \\
\hline - $\quad$ on-farm excl. veenmineralisatie (kg CO2-eq./ha) & 15.842 & 15.675 & 18.445 & 17.950 & 14.430 & 14.627 & 15.751 & 16.057 \\
\hline - $\quad$ totaal excl. veenmineralisatie (kg CO2-eq./ha) & 21.787 & 22.101 & 24.125 & 24.149 & 19.772 & 20.550 & 21.408 & 22.419 \\
\hline \multicolumn{9}{|l|}{ Broeikasgasemissie per ton melk } \\
\hline - $\quad$ on-farm (kg CO2-eq./ton melk) & 1.085 & 1.072 & 1.368 & 1.374 & 1.030 & 1.023 & 1.139 & 1.131 \\
\hline - $\quad$ totaal (kg CO2-eq./ton melk) & 1.481 & 1.497 & 1.751 & 1.806 & 1.401 & 1.424 & 1.525 & 1.550 \\
\hline - $\quad$ totaal excl. veenmineralisatie (kg CO2-eq./ton melk) & 1.481 & 1.497 & 1.662 & 1.713 & 1.401 & 1.424 & 1.502 & 1.526 \\
\hline \multicolumn{9}{|l|}{ Bedrijfsstructuur } \\
\hline Intensiteit (kg melk/ha) & 14.953 & 15.044 & 14.796 & 14.424 & 14.437 & 14.772 & 14.585 & 15.130 \\
\hline Oppervlakte (ha) & 64 & 64 & 60 & 60 & 61 & 61 & 73 & 74 \\
\hline Aandeel maisland (\%) & $3 \%$ & $3 \%$ & $5 \%$ & $5 \%$ & $14 \%$ & $14 \%$ & $10 \%$ & $10 \%$ \\
\hline Aandeel klei (\%) & 100 & 100 & 0 & 0 & 0 & 0 & 29 & 28 \\
\hline Aandeel veen (\%) & 0 & 0 & 100 & 100 & 0 & 0 & 25 & 26 \\
\hline Aandeel zand (\%) & 0 & 0 & 0 & 0 & 100 & 100 & 46 & 46 \\
\hline Melkproductie bedrijf ( $\mathrm{kg}$ melk per bedrijf) & 979.284 & 982.402 & 898.915 & 882.373 & 890.913 & 897.703 & 1.072 .685 & 1.137 .617 \\
\hline Melkproductie per koe (kg melk/koe) & 8.088 & 8.368 & 7.970 & 8.197 & 8.175 & 8.515 & 8.073 & 8.483 \\
\hline Aantal koeien & 119 & 115 & 110 & 105 & 107 & 103 & 131 & 131 \\
\hline Aantal GVE per koe (GVE/koe) & 1,23 & 1,22 & 1,22 & 1,21 & 1,25 & 1,23 & 1,24 & 1,23 \\
\hline Uren weidegang & 1.173 & 1.215 & 1.120 & 1.022 & 932 & 1.029 & 964 & 985 \\
\hline
\end{tabular}





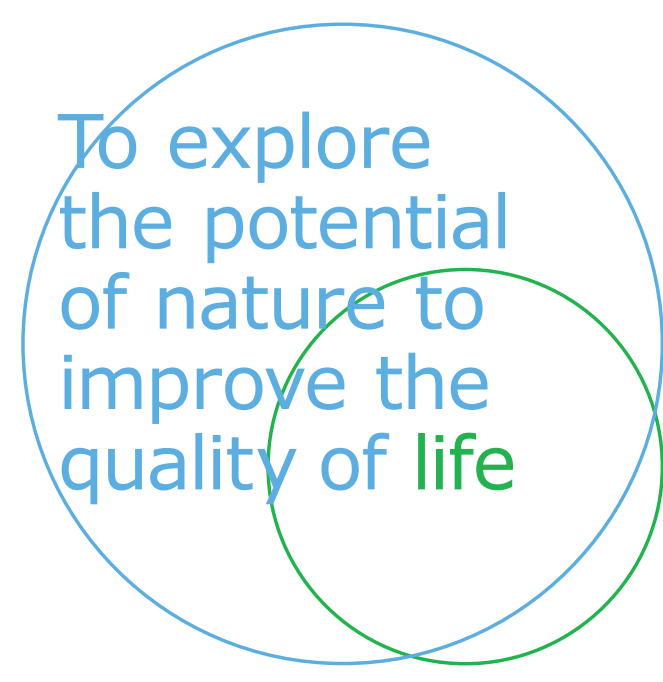

Wageningen Livestock Research Postbus 338 $6700 \mathrm{AH}$ Wageningen

T 0317483953

E info.livestockresearch@wur.nl www.wur.nl/ livestock-research

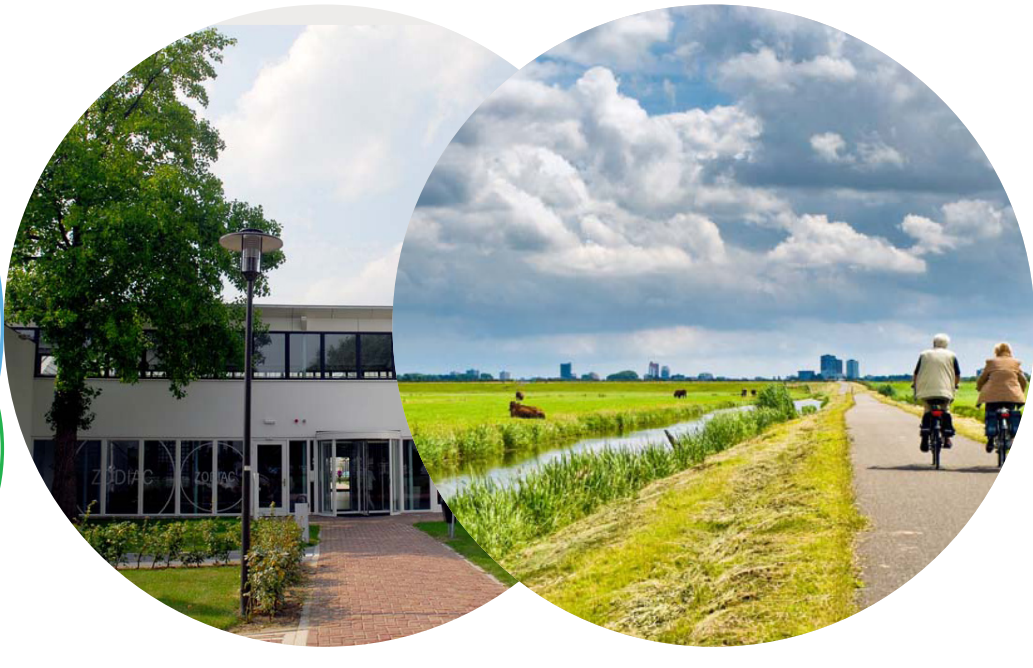

Wageningen Livestock Research ontwikkelt kennis voor een zorgvuldige en renderende veehouderij, vertaalt deze naar praktijkgerichte oplossingen en innovaties, en zorgt voor doorstroming van deze kennis. Onze wetenschappelijke kennis op het gebied van veehouderijsystemen en van voeding, genetica, welzijn en milieu-impact van landbouwhuisdieren integreren we, samen met onze klanten, tot veehouderijconcepten voor de $21 \mathrm{e}$ eeuw.

De missie van Wageningen University \& Research is 'To explore the potential of nature to improve the quality of life'. Binnen Wageningen University \& Research bundelen 9 gespecialiseerde onderzoeksinstituten van Stichting Wageningen Research en Wageningen University hun krachten om bij te dragen aan de oplossing van belangrijke vragen in het domein van gezonde voeding en leefomgeving. Met ongeveer 30 vestigingen, 6.500 medewerkers en 10.000 studenten behoort Wageningen University \& Research wereldwijd tot de aansprekende kennisinstellingen binnen haar domein. De integrale benadering van de vraagstukken en de samenwerking tussen verschillende disciplines vormen het hart van de unieke Wageningen aanpak. 